\title{
Regulation of $\mathrm{p} 27^{\mathrm{Kip} 1}$ by Sox2 Maintains Quiescence of Inner Pillar Cells in the Murine Auditory Sensory Epithelium
}

\author{
Zhiyong Liu, ${ }^{1,3 \star}$ Brandon J. Walters, ${ }^{1 \star}$ Thomas Owen, ${ }^{1,4}$ Mark A. Brimble, ${ }^{1,4}$ Katherine A. Steigelman, ${ }^{1}$ LingLi Zhang, ${ }^{1}$ \\ Marcia M. Mellado Lagarde, ${ }^{1}$ Marcus B. Valentine, ${ }^{2}$ Yiling Yu, ${ }^{1,5}$ Brandon C. Cox, ${ }^{1}$ and Jian Zuo ${ }^{1}$ \\ Departments of ${ }^{1}$ Developmental Neurobiology and ${ }^{2}$ Tumor Cell Biology, St. Jude Children's Research Hospital, Memphis, Tennessee 38105, ${ }^{3}$ Integrated \\ Program In Biomedical Sciences, University of Tennessee Health Science Center, Memphis, Tennessee 38163, ${ }^{4}$ University of Bath, Bath BA2 7AY, United \\ Kingdom, and ${ }^{5}$ Shanghai Medical School, Fudan University, Shanghai, People's Republic of China
}

Sox2 plays critical roles in cell fate specification during development and in stem cell formation; however, its role in postmitotic cells is largely unknown. Sox2 is highly expressed in supporting cells (SCs) of the postnatal mammalian auditory sensory epithelium, which unlike non-mammalian vertebrates remains quiescent even after sensory hair cell damage. Here, we induced the ablation of Sox2, specifically in SCs at three different postnatal ages (neonatal, juvenile and adult) in mice. In neonatal mice, Sox2-null inner pillar cells (IPCs, a subtype of SCs) proliferated and generated daughter cells, while other SC subtypes remained quiescent. Furthermore, p27 Kip1 , a cell cycle inhibitor, was absent in Sox2-null IPCs. Similarly, upon direct deletion of p27 ${ }^{\text {Kip1 }}$, p2 ${ }^{\text {Kip1 }}{ }_{\text {-null IPCs also proliferated but }}$ retained Sox 2 expression. Interestingly, cell cycle control of IPCs by Sox2-mediated expression of p $27^{\text {Kip1 }}$ gradually declined with age. In addition, deletion of Sox 2 or p $27^{\mathrm{Kip} 1}$ did not cause a cell fate change. Finally, chromatin immunoprecipitation with Sox 2 antibodies and luciferase reporter assays with the $p 27^{\text {Kip } 1}$ promoter support that Sox 2 directly activates $p 27^{\text {Kip } 1}$ transcription in postmitotic IPCs. Hence, in contrast to the well known activity of Sox 2 in promoting proliferation and cell fate determination, our data demonstrate that Sox 2 plays a novel role as a key upstream regulator of $\mathrm{p} 27^{\mathrm{Kip} 1}$ to maintain the quiescent state of postmitotic IPCs. Our studies suggest that manipulating Sox 2 or $\mathrm{p} 27^{\mathrm{Kip} 1}$ expression is an effective approach to inducing proliferation of neonatal auditory IPCs, an initial but necessary step toward restoring hearing in mammals.

\section{Introduction}

The mouse cochlear sensory epithelium, also referred to as the organ of Corti, contains one row of inner hair cells (IHCs); three rows of outer hair cells (OHCs) along with adjacent supporting cell (SC) subtypes such as inner pillar cells (IPCs), outer pillar cells (OPCs) and Deiters' cells (DCs) whose nuclei reside at the level below the hair cell (HC) bodies. In the

\section{Received Feb. 13, 2012; revised May 28, 2012; accepted May 31, 2012.}

Author contributions: Z.L., B.J.W., and J.Z. designed research; Z.L., B.J.W., T.O., M.A.B., K.A.S., L.Z., M.M.M.L., M.B.V., and Y.Y. performed research; Z.L., B.J.W., and M.A.B. analyzed data; Z.L., B.J.W., B.C.C., and J.Z. wrote the paper.

This work was supported by grants from the National Institutes of Health: DC06471 (J.Z.), DC05168 (J.Z.), DC008800 (J.Z.), 1F31DC009393 (K.A.S.), 1F32DC010310 (B.C.C.), and CA21765; Office of Naval Research: N000140911014 and N000141210191 (J.Z.); Sir Henry Wellcome Trust Fellowship (M.M.M.-L.); the American Lebanese Syrian Associated Charities (ALSAC) of St. Jude Children's Research Hospital; and Travel Awards from Academic Programs of St. Jude Children's Research Hospital (Z.L.), University of Tennessee Health Science Center (Z.L.), and Society of Developmental Biology (Z.L.). J.Z. is a recipient of The Hartwell Individual Biomedical Research Award. We thank Dr. M. Mishina for providing Sox2 ${ }^{\text {IoxP/loxP }}$ mice (RBRC01897) through the RIKEN Center in Japan, Dr. W. Richardson (University College London) for the Fgfr $3^{\text {icreeR }+}$ mice, Dr. G. Oliver (St. Jude Children's Research Hospital) for the Prox $7^{\text {CreER/+ }}$ mice, Dr. M. Fero (Fred Hutchinson Cancer Research Center) for the $227^{\text {loxP/IoxP }}$ mice, Dr. J. Robbins (Cincinnati Children's Hospital Medical Center) for the CAG-EGFP+ reporter mice, Dr. Sakai (Kyoto Prefectural University of Medicine) for the $p 27^{\text {Kip } 1}$-luciferase vector, and Dr. M. Kundu (St. Jude Children's Research Hospital) for the immortalized MEF cells.

The authors declare no competing financial interests.

*Z.L. and B.J.W. contributed equally to this work.

Correspondence should be addressed to Dr. Jian Zuo, Department of Developmental Neurobiology, St. Jude Children's Research Hospital, 262 Danny Thomas Place, Memphis, TN 38105. E-mail: jian.zuo@stjude.org.

DOI:10.1523/JNEUROSCI.0686-12.2012

Copyright $\odot 2012$ the authors $\quad 0270-6474 / 12 / 3210530-11 \$ 15.00 / 0$ prosensory phase of cochlear development, prosensory progenitors are specified and continue proliferating until $p 27^{\text {Kip } 1}$, a Cip/Kip family cell cycle inhibitor, is turned on in an apical to basal gradient between embryonic day 12.5 (E12.5) and E14.5 (Lee et al., 2006). After cell cycle exit, these progenitors differentiate into either HCs or SCs in a process mediated by Notch1 signaling (Lanford et al., 1999; Liu et al., 2012a) and Atoh1 (Bermingham et al., 1999).

Sox 2 can both regulate the cochlear prosensory area formation (Kiernan et al., 2005) and mediate the cell fate of these progenitors by antagonizing Atoh1 (Dabdoub et al., 2008). As differentiation advances, Sox 2 and $\mathrm{p} 27^{\mathrm{Kip} 1}$ are gradually limited to SCs and become undetectable in HCs by birth. Although the details are unknown, p2 $7^{\mathrm{Kip} 1}$ has been shown to keep postnatal SCs quiescent (Ono et al., 2009; Oesterle et al., 2011). However, the roles of Sox 2 in postnatal SCs remain unclear.

When auditory HCs are damaged in non-mammalian vertebrates such as birds, fish and amphibians, SCs proliferate and trans-differentiate into HCs (Stone and Cotanche, 2007; Brigande and Heller, 2009). Unfortunately, mammals are unable to regenerate auditory HCs after damage and SCs are tightly kept quiescent. Interestingly, SCs isolated from neonatal mice can spontaneously downregulate $p 27^{K i p 1}$, proliferate and differentiate into HC-like cells when cultured in vitro (White et al., 2006). Although the mechanism remains elusive, this finding not only provides a promising approach to regenerate auditory HCs 


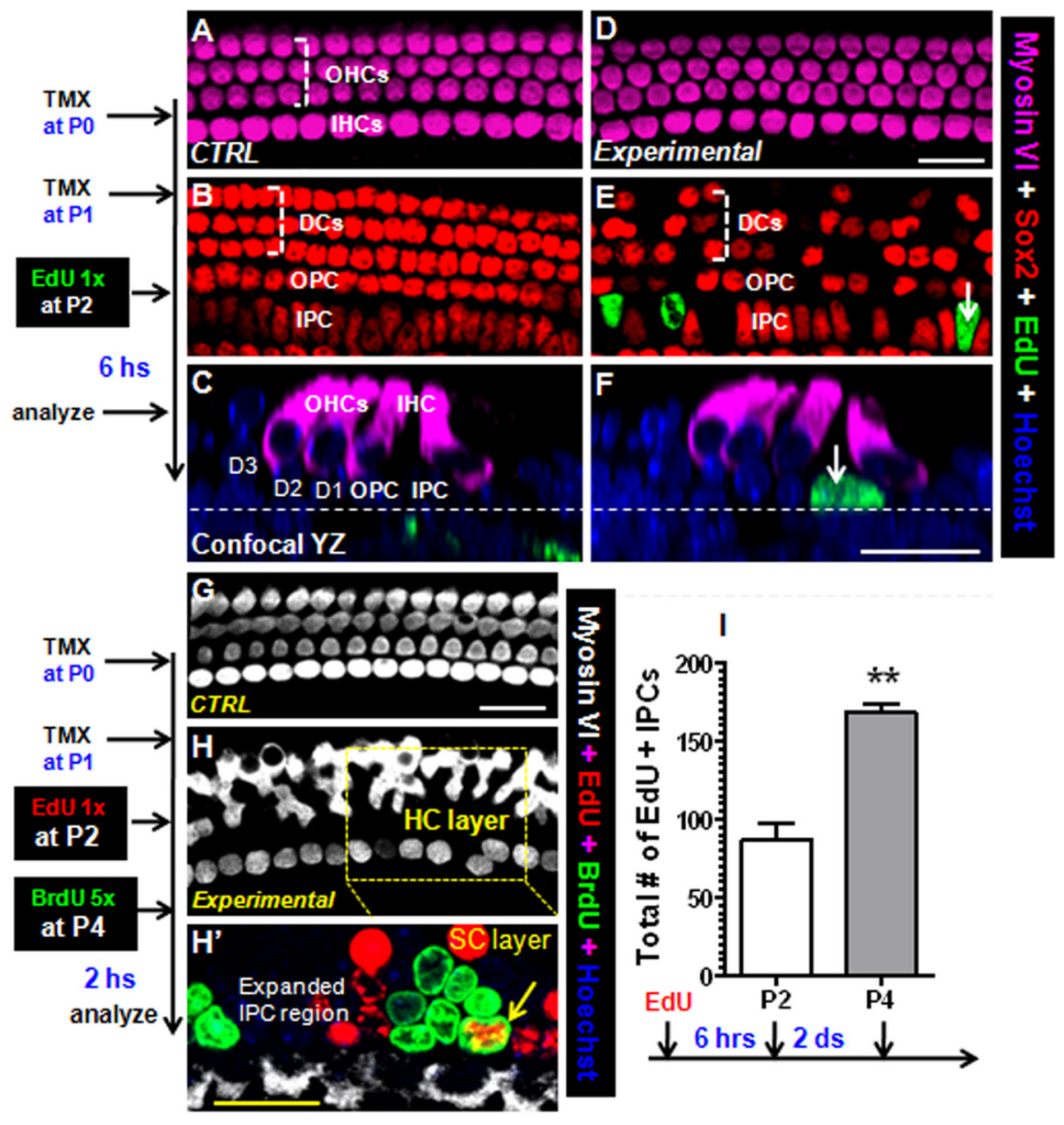

Figure 1. Deletion of Sox2 leads to proliferation of neonatal IPCS. $\boldsymbol{A}-\boldsymbol{F}$, Triple staining of myosin VI, Sox2, and EdU in $\mathrm{Fgfr}^{\text {icreeR }+} ; \mathrm{Sox2}^{+/+}$control $(\boldsymbol{A}-\boldsymbol{C})$ and Fgfr3 ${ }^{\text {icreeR }+} ;$; Sox $2^{\text {loxP/loxP }}$ experimental $(\boldsymbol{D}-\boldsymbol{F})$ samples given tamoxifen at $\mathrm{PO}$ and $\mathrm{P} 1$ at the $H C$ layer $(\boldsymbol{A}, \boldsymbol{D})$ and $S C$ layer $(\boldsymbol{B}, \boldsymbol{E})$. $\boldsymbol{C}$ and $\boldsymbol{F}$ are artificial cross-section images in the $Y Z$ plane. Arrows in $\boldsymbol{E}$ and $\boldsymbol{F}$ point to the same EdU + /Sox2-negative IPC. Dashed lines in C and $\boldsymbol{F}$ represent the basilar membrane. $\mathbf{G}-\boldsymbol{H}^{\prime}$, Control $(\boldsymbol{G})$ and experimental $\left(\boldsymbol{H}-\boldsymbol{H}^{\prime}\right)$ samples were stained with myosin $\mathrm{VI}, \mathrm{EdU}$, and BrdU. $\boldsymbol{G}$ and $\boldsymbol{H}$ are images taken at the $\mathrm{HClayer}$, and $\boldsymbol{H}^{\prime}$ at the SC layer. Arrow in $\boldsymbol{H}^{\prime}$ shows an EdU + /BrdU + IPC.I, Quantification of EdU + IPCs in the entire cochlea of experimental samples given TMX at P0 and P1, $\mathrm{EdU}$ at $\mathrm{P} 2$, and analyzed $6 \mathrm{~h}$ later or at $\mathrm{P} 4 .{ }^{* *} p<0.01(n=3)$. Scale bars, $20 \mu \mathrm{m}$.

in mammals, but also highlights the importance of understanding how the quiescent state of postnatal SCs is maintained and identifying upstream regulator(s) of $p 27^{\text {Kip } 1}$.

Using the tamoxifen-inducible CreER/loxP system, we deleted Sox 2 in cochlear SCs at different postnatal ages. We found that Sox2-null IPCs lost expression of p $27^{\text {Kip } 1}$ and proliferated. This proliferative capacity declined with maturation. In addition, when $\mathrm{p} 27^{\mathrm{Kip} 1}$ was deleted, IPCs proliferated but maintained expression of Sox2. Furthermore, in vitro studies illustrated that Sox 2 physically binds to the promoter of $p 27^{K i p 1}$. Together, our data show that Sox 2 is a key regulator in maintaining $p 27^{\text {Kip } 1}$ expression and quiescence in IPCs.

\section{Materials and Methods}

Mice and tamoxifen treatment. Sox $2^{\text {loxP/loxP }}, \operatorname{Prox} 1^{\text {CreER/+ }}$, p27 loxP/loxP, $\mathrm{Fgfr} 3^{i \mathrm{CreER+}}$, and $C A G-E G F P+$ reporter mice were generated as described previously (Chien et al., 2006; Nakamura et al., 2006; Srinivasan et al., 2007; Miyagi et al., 2008; Young et al., 2010). Rosa26EYFP $^{\text {loxP/+ }}$ (stock \# 006148) and Rosa26-CAG-tdTomato ${ }^{\text {loxP/+ }}$ (Ai14, stock \# 007914) reporter mice were obtained from The Jackson Laboratory. Neonatal or juvenile mice were given tamoxifen $(3 \mathrm{mg} / 40 \mathrm{~g})$ at postnatal day 0 (P0) and P1 (24 h interval), or P6 and P7 (24 h interval). Adult mice were given tamoxifen $(9 \mathrm{mg} / 40 \mathrm{~g})$ at P30 once only. Mice of either sex were used for all experiments. All animal work conducted during the course of this study was approved by the Institutional Animal Care and Use Committee at St. Jude Children's Research Hospital and was performed according to $\mathrm{NIH}$ guidelines.

Tissue preparation, immunofluorescence, and analysis. After fixing in 4\% PFA overnight, whole-mount cochlear tissues were divided into 3 parts. After scanning each part with a confocal microscope (Zeiss LSM 700) with a $10 \times$ lens, the total length of cochleae was measured. Then, each cochlea was divided into 3 turns of equal length (apical, middle, and basal).

The following primary antibodies were used for immunostaining following protocols that were described previously (Liu et al., 2010; Yu et al., 2010): anti-myosin VI (1:200, 25-6791, Proteus Bioscience), anti-myosin VIIa (1:200, 25-6790, Proteus Bioscience), anti-BrdU (1:50, B35130/B35131/B35133, Invitrogen), antiProx1 (1:500, AB5475, Millipore), anti-calbindin (1:500, AB1778, Millipore), anti-p75 ${ }^{\mathrm{NGFR}}$ (1: 1000, AB1554, Millipore), anti-GFP (1:1000, ab13970, Abcam), anti-p27 Kip1 (1:500, 610242, BD Transduction Laboratories), anti-Sox2 (1: 1000, sc-17320, Santa Cruz Biotechnology) and anti-phospho-histone 3 (pH3) (1:20, 9708, Cell Signaling Technology). All secondary antibodies were purchased from Invitrogen and used as 1:1000 dilutions.

For $\mathrm{p} 27^{\text {Kip } 1}$ whole-mount staining, an antigen retrieval process (H-3300, Vector Laboratories) was performed, followed by the Tyramide Signal Amplification Kit (T20912, Invitrogen). For cell death measurements, TUNEL staining was performed with the In Situ Cell Death Detection kit, Fluorescein, or TMR Red (11684795910 or 12156792910 , Roche Applied Science) following the manufacturer's instructions. EdU (5-ethynyl-2'deoxyuridine) labeling was performed using the Click-iT EdU labeling kit (Invitrogen, C10337/C10338/C10340) following the manufacturer's instructions.

Luciferase assays. Plasmids containing the $p 27^{\text {Kip } 1}$ promoter driving luciferase and the empty luciferase control were obtained from Dr. Toshiyuki Sakai (Kyoto Prefectural University of Medicine, Kyoto, Japan). LacZ, E2F1, and Sox2 expression vectors were obtained from Addgene (plasmid 18816, 10736, and 13459). Luciferase and $\beta$-galactosidase activity were assayed by the Applied Biosystems DualLight kit and quantitated on a Glomax Multi+ plate reader (Promega). Plasmids were cotransfected into $\sim 10,000$ MEF (mouse embryonic fibroblast), HeLa, or HEK (human embryonic kidney) cells using Lipofectamine LTX (Invitrogen), following the manufacturer's protocol (7:1 LTX/DNA ratio). HEK and immortalized MEF cells were obtained from Dr. M. Kundu (St. Jude's Children's Research Hospital, Memphis, TN). HeLa cells were obtained from ATCC.

Chromatin immunoprecipitation assay. Chromatin immunoprecipitation (ChIP) was performed on MEF cells which had been transfected with both the p2 $7^{\text {Kip1 }}$-luciferase vector and Sox 2 using the Simple ChIP Magnetic kit (Cell Signaling Technology). DNA was first precleared with overnight incubation with the IgG antibody followed by $30 \mathrm{~min}$ incubation with the magnetic beads, which were discarded. Next DNA/protein complexes were immunoprecipitated using $2 \mu \mathrm{l}$ of ChIP-formulated Sox 2 antibody (Cell Signaling Technology, 5024). DNA was liberated, purified and then quantified by qPCR using SYBR Green (Bio-Rad) on an Eppendorf RealPlex ${ }^{2}$. A total of 9 sets of primer pairs covering $\sim 2 \mathrm{~kb}$ of contiguous $\mathrm{p} 27^{\mathrm{kip} 1}$ promoter and 1 nonspecific primer pair located downstream of the luciferase open 
reading frame were examined for enrichment of the amplicon over background $\left(2^{\left(C_{\mathrm{t}} \mathrm{Sox} 2\right)-\left(C_{\mathrm{t}} \mathrm{IgG}\right)}\right)$. These values were then normalized to the nonspecific downstream amplicon. The primer pair sequences (forward, reverse, from $5^{\prime}$ to $3^{\prime}$ ) are as follows: Primer 1, CTCCGAGGGCAG TCGC, GGTGGCTTTACCAACAGTACC; Primer 2, CTCCCCTGTCCCCGCTTGC, AA GACACAGACCCCGACGAGCCAC; Primer 3, GAGGGGAGGTGGCGGAA, GCAAGCGG GGACAGGGGA;Primer4,CCGTTTGGCTAG TTTGTTGTCT, CCGAGGCTGGCGAGC; Primer 5, AGCCCCCCCAGCAAA, AGACAA ACAAACTAGCCAAACGG; Primer 6, TTAA TCTTGAGTTCCTTTCTTAATTTC, TGGTCT GCGGGGGAGGC; Primer 7, GGGAAAGAAC AGAAAAGTAGAAAG, TCATTTCATCATCT GGAGTTTGACCC; Primer 8, TCATTTCATC ATCTGCAGTTTGACCC, TCGTCCCTTTCT ACTTTTCTGTTCTTT; Primer 9, GGGGAG GCAGTTGAAGATCCACTGA, CGGGGTCA AACTCCAGATGATGAAAT; Nonspecific downstream primer pair: TGTTTCAGGTTC AGGGGGAGG， GGAGCTGACTGGGT TGAAGG.

Statistical analyses. All data are expressed as mean \pm SEM. Significance was calculated using a Student's $t$ test with a Bonferroni correction. GraphPad Prism 5.0 was used for all statistical analyses.

\section{Results}

Neonatal IPCs proliferate and generate daughter cells after deletion of Sox 2

In the postnatal cochlea, Sox 2 is highly expressed in SCs inside the organ of Corti, in cells of the greater epithelial ridge and in Hensen's cells which are lateral to the organ of Corti (Liu et al., 2012c). To determine the roles of Sox 2 in IPCs, OPCs and DCs, we first tried to breed Sox $2^{\text {loxP/loxP }}$ mice with our previously characterized Prox $1^{\text {CreER/+ }}$ line whose Cre activity is restricted to pillar cells (PCs) and DCs when tamoxifen is given at P0 and P1 (Yu et al., 2010). However, for reasons unknown, it was very difficult to get Prox $1^{\text {CreER+ }}$;Sox $2^{\text {loxP/loxP }}$ mice by breeding both lines. Therefore, we instead characterized the $\mathrm{Fgfr} 3^{i \mathrm{CreER}+}$ transgenic mouse (Young et al., 2010). When tamoxifen was given at P0 and P1, inside the organ of Corti, the iCre activity of $\mathrm{Fgfr} 3^{i \mathrm{CreER}+}$ is primarily restricted into IPCs, OPCs, and DCs (Cox et al., 2012). Of note, iCre+ OHCs, Hensen's cells or Claudius cells were also observed, but iCre + IHCs and inner phalangeal cells (IPHs) were never observed. Although Cre activity of $\mathrm{Fg} f \mathrm{r} 3^{\mathrm{iCreER+}}$ mice was not entirely specific to SCs, it was suitable for our study because Sox2 is normally undetectable in all postnatal HCs (Liu et al., 2012b). In the current study, we focused on IPCs, OPCs, and DCs.

$F g f r 3^{i C r e E R+} ;$ Sox $2^{\text {loxP } / l o x P}$ mice were used to delete Sox 2 . Three control groups were used: (1) $\mathrm{Fgfr} 3^{\mathrm{iCreER}+}$; Sox $2^{+/+}$mice with identical tamoxifen injections to rule out the possibility that the observed phenotypes were caused by tamoxifen itself; (2) Fgfr $3^{i C r e E R+}$; Sox $2^{\text {loxP/loxP }}$ mice without tamoxifen injection to ensure that $\operatorname{Sox} 2^{\operatorname{lox} P / \operatorname{lox} P}$ alleles without Cre-mediated recombination are equivalent to Sox $2^{+/+}$alleles; and (3) Fgfr $3^{i C r e E R+}$; Sox $2^{\text {loxP/+ }}$ mice with identical tamoxifen injections to test whether one copy of Sox2 is haploinsufficient.

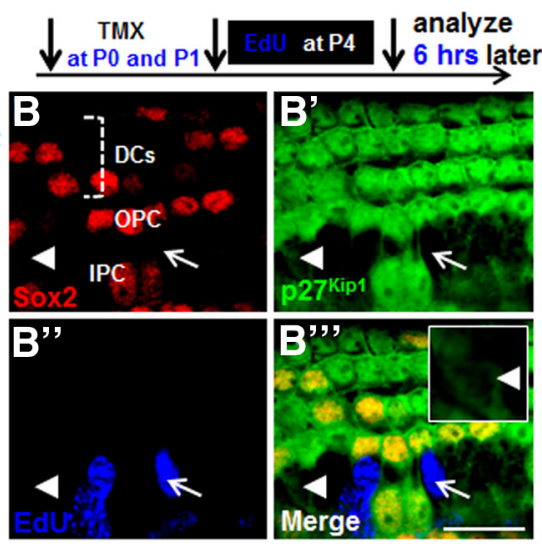

CTRL

Experimental
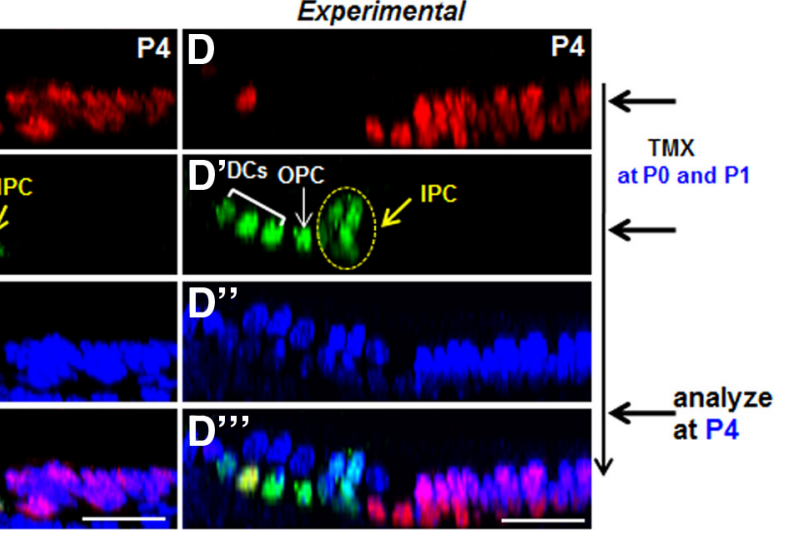

Figure 2. Deletion of Sox2 results in loss of $p 27^{\text {Kip } 1}$ expression in neonatal IPCs without cell fate change. A, Quantification of Sox2negative and p27 $7^{\text {Kip } 1}$-negative IPCs at P2 in the entire cochlea of $F g f r 3^{j(r e E R+} ;$ Sox2 ${ }^{\text {loxP/loxP }}$ experimental mice injected with tamoxifen at PO and P1. $\boldsymbol{B}-\boldsymbol{B}^{\prime \prime}$, Triple staining of Sox2, $\mathrm{p}^{2} \mathrm{~K}_{\mathrm{ip}}$, and EdU in cochlear samples from experimental mice. Arrows point to the same EdU +1 was EdU-negative, which is also visualized at a higher magnification (inset in $\left.\boldsymbol{B}^{\prime \prime \prime}\right)$. $\mathbf{C}-\boldsymbol{D}^{\prime \prime}$, Double labeling of Sox2 and Prox1 in control

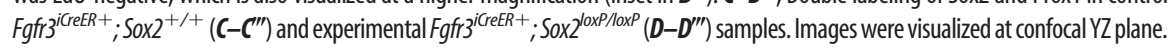
More IPCs were present in experimental (dashed circle in $\boldsymbol{D}^{\prime}$ ) than in control groups. Scale bars, $20 \mu \mathrm{m}$.

None of the control groups had phenotypes, thus we only present data from the Fgfr $3^{i \text { CreER+ }}$; Sox $2^{\text {loxP/loxP }}$ mice (experimental group) and $\mathrm{Fg} f \mathrm{r}^{\mathrm{iCreER+}}$; Sox $2^{+/+}$mice (control group).

Both groups were given tamoxifen at $\mathrm{P} 0$ and $\mathrm{P} 1$, EdU once at $\mathrm{P} 2$ and analyzed $6 \mathrm{~h}$ later (Fig. $1 A-F$ ). While Sox 2 was maintained in all IPCs, OPCs, and DCs in control mice (Fig. $1 B$ ), Sox2-negative IPCs, OPCs, and DCs were found in all cochlear turns of experimental mice (Fig. $1 E$ ). There was no significant difference in the length of the cochlea between control $(5700 \pm 200 \mu \mathrm{m})$ and experimental groups $(5800 \pm 185 \mu \mathrm{m})$ by $\mathrm{P} 2$ when the cochlea has reached its final length (Morsli et al., 1998). Control mice had no EdU+ SCs inside the organ of Corti (Fig. $1 B$ ), while EdU+ mesenchymal cells were observed below the basilar membrane (Fig. 1C, dashed line) which serve as an internal positive control for EdU staining. In contrast, scanning the entire cochlea by confocal microscopy revealed $86 \pm 11$ EdU + cells $(n=3)$ (all Sox2-negative) in each experimental mouse: $\sim 81 \%$ were in apical turns and $\sim 19 \%$ in middle turns. Interestingly, all EdU + cells were IPCs, defined by their unique oblong nuclei and location (Fig. 1E,F, arrows). This implies that Sox2 ablation at P0 and $\mathrm{P} 1$ leads to $\mathrm{S}$ phase reentry of IPCs only.

We also found EdU+/pH3 + IPCs (data not shown), indicating Sox2-negative IPCs entered M phase. To further determine whether EdU+ IPCs could complete the cell cycle and generate new daughter cells, EdU was given once at P2, followed by 5 injections of BrdU (at $2 \mathrm{~h}$ intervals) at $\mathrm{P} 4$ and analyzed $2 \mathrm{~h}$ later after the last BrdU injection 


\section{CTRL}
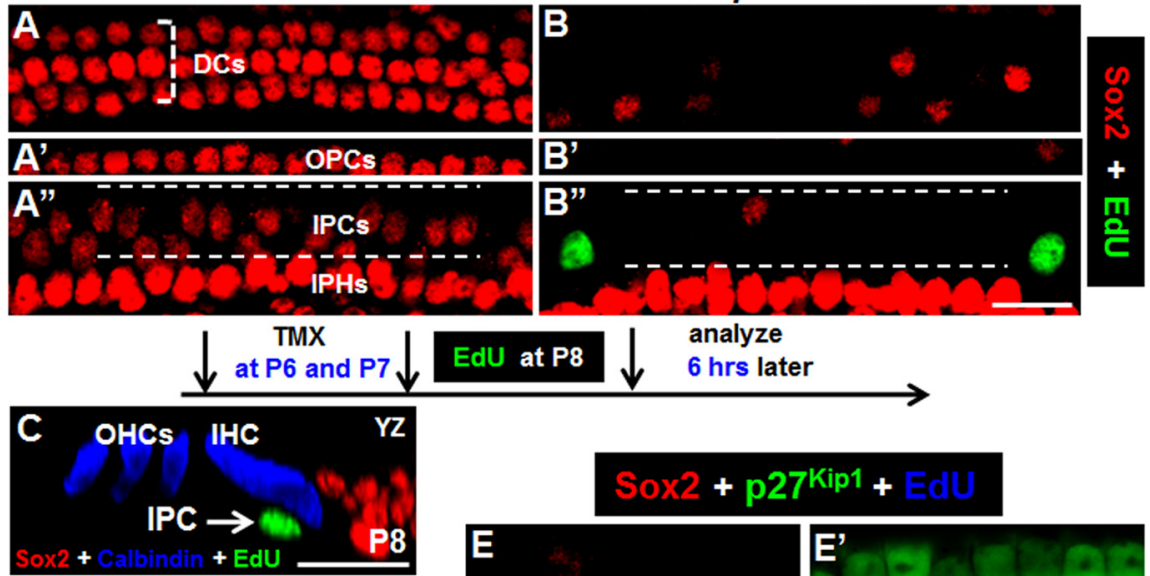

$D \sqsubset$ Sox2-negative IPCs at P8

$\square$ Sox2/p27-negative IPCs at P8

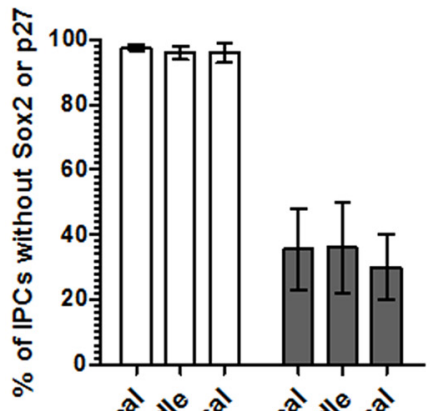

๙ீ

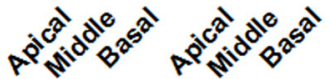

Experimental
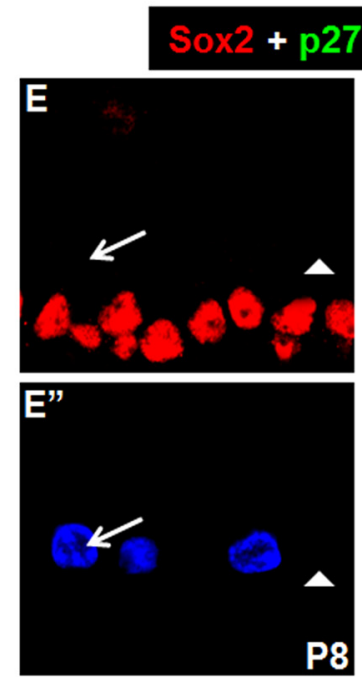

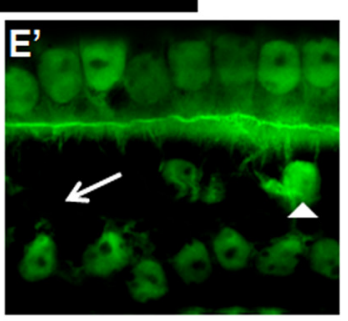

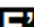

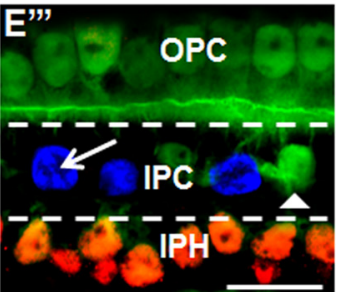

Figure 3. Sox2 ablation causes a loss of $p 27^{K i p 1}$ expression and $S$ phase reentry of juvenile IPCS. $\boldsymbol{A}-\boldsymbol{B}^{\prime \prime}, \mathrm{Fgfr}^{\text {icreeR }+} ; \mathrm{SONO}^{+/+}$ control $\left(\boldsymbol{A}-\boldsymbol{A}^{\prime \prime}\right)$ and $F g f \mathrm{~F}^{\text {icreeR }+} ;$; Sox $2^{\text {loxP/loxP }}$ experimental $\left(\boldsymbol{B}-\boldsymbol{B}^{\prime \prime}\right)$ samples given tamoxifen at P6 and P7 were stained with Sox2 and EdU. Each panel represents a single confocal slice taken at a different layer. $\boldsymbol{C}$, Artificial cross-section image visualized in the confocal YZ plane in experimental samples triple stained with Sox2, calbindin and EdU. D, Quantification of Sox2-negative and

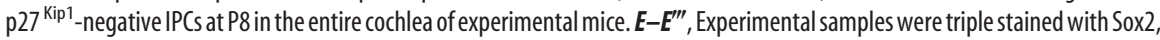

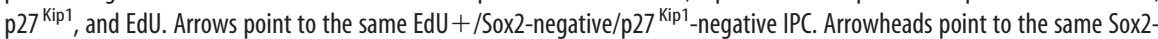
negative IPC that maintained expression of $\mathrm{p} 27^{\mathrm{Kip} 1}$ and was EdU-negative. IPHs maintained normal Sox2 expression and were EdU-negative. Scale bars, $20 \mu \mathrm{m}$.

(Fig. $1 G, H^{\prime}$ ). Quantification of the entire cochlea revealed 3 types of IPCs: EdU + only, BrdU+ only and EdU +/BrdU + . The presence of $\mathrm{EdU}+/ \mathrm{BrdU}+\mathrm{IPCs}(45 \pm 5$ cells, $n=3$ ) demonstrated that proliferating IPCs that incorporated EdU at P2 gave birth to daughter cells, which reentered S phase and incorporated BrdU at P4 (Fig. $1 H^{\prime}$, arrow). Consistently, there were significantly more EdU+ IPCs (both single EdU + and EdU $+/ \mathrm{BrdU}+$ ) at $\mathrm{P} 4$ than at P2 (Fig. $1 I$ ). In addition, $90 \%$ of EdU+/BrdU+ IPCs were distributed in apical turns and $10 \%$ in middle turns, while $85 \%$ of IPCs that were only $\mathrm{EdU}+$ were in apical turns and $15 \%$ in middle turns. Interestingly, $80 \%$ of IPCs that were only BrdU+ were in apical turns, $17 \%$ in middle turns and 3\% in basal turns. This suggests that Sox2-negative IPCs in basal turns began to reenter S phase at P4, 2 d later than IPCs in apical and middle turns.

Next, we probed the mechanism underlying the apical-to-basal gradient numbers of EdU + IPCs and the delay in proliferation of IPCs in basal turns. While $\sim 55 \%$ of IPCs were Sox2-negative throughout the entire cochlea at P2, $\sim 23 \%$ of IPCs were p $27^{\text {Kip1 }}$ negative in apical turns, $\sim 2.5 \%$ of IPCs were $\mathrm{p} 27^{\mathrm{Kip} 1}$-negative in middle turns and all IPCs retained p $27^{\text {Kip } 1}$ expression in basal turns (Fig. 2A). This suggests that repression of $\mathrm{p} 27^{\mathrm{Kip} 1}$ following Sox2 deletion determines the proliferative capacity of IPCs and is supported by the presence of Sox 2 -negative/p2 $27^{\mathrm{Kip} 1}$-negative/EdU+
IPCs in apical, middle and basal turns at P4 (Fig. $2 B-B^{\prime \prime \prime}$, arrows). In addition, all EdU+ IPCs were Sox2-negative/p2 $7^{\text {Kip } 1}$-negative. Note that there were Sox2-negative/EdUnegative IPCs where faint, but detectable, p $27^{\text {Kipl }}$ expression was present (Fig. $2 B-B^{\prime \prime \prime}$, arrowheads). We could not determine the percentage of Sox2-negative or p $27^{\text {Kip } 1}$-negative IPCs in each turn at P4 or older ages primarily because newly generated daughter cells were also Sox2negative/p2 ${ }^{\text {Kip } 1}$-negative and were different from original Sox2-negative/ p2 $7^{\text {Kip } 1}$-negative IPCs obtained by Cremediated recombination (Fig. 2A). Moreover, we could not determine whether Sox2-negative/p27 Kip1 + IPCs later become p $27^{\mathrm{Kip} 1}$-negative.

In contrast, all OPCs and DCs (either Sox $2+$ or Sox2-negative) retained expression of $\mathrm{p} 27^{\mathrm{Kip} 1}$ at $\mathrm{P} 4$ (Fig. $2 B-B^{\prime \prime \prime}$ ), and we never observed EdU+ OPCs or DCs. We did not analyze samples at older ages because we also could not distinguish OPCs from new daughter cells produced by proliferating IPCs. Together, our results suggest that p27 Kip1 downregulation after Sox 2 ablation determines the proliferative capacity of IPCs, whereas ablation of Sox2 in OPCs and DCs does not result in proliferation because $\mathrm{p} 27^{\mathrm{Kip} 1}$ expression is maintained.

\section{Daughter cells born from neonatal} proliferating IPCs maintain the SC fate In control mice, Prox 1 is expressed in neonatal IPCs, OPCs, and DCs (Fig. 2C$\left.C^{\prime \prime \prime}\right)$; thus, we used Prox1 as a marker to define SC fate. Prox1 expression was maintained in all Sox2-negative IPCs, OPCs, and DCs at P4 (Fig. $2 D-D^{\prime \prime \prime}$ ). We did not analyze samples at older ages, because Prox1 is normally downregulated with age (Bermingham-McDonogh et al., 2006). Nonetheless, our results suggest that Sox 2 is not required to maintain Prox1 expression and Sox2-null SCs maintain their intrinsic cell fate until P4. In addition, there were no EdU + (or BrdU +$) /$ myosin $\mathrm{VI}+$ cells or extra HCs in cochlear samples analyzed at P2 and P4 (Fig. 1). This observation not only verifies our assumption that deletion of Sox 2 in a few iCre+ OHCs at P0 and P1 does not result in a detectable phenotype, but also suggests that there is no cell fate conversion from proliferative IPCs to HCs by $\mathrm{P} 4$ when Sox 2 is deleted.

\section{Juvenile IPCs reenter S phase and M phase but do not} proliferate after deletion of Sox 2

Cochlear development significantly advances within the first week after birth. Therefore, we deleted Sox2 in SCs at P6 and P7 (defined as juvenile SCs) to determine whether they still need Sox2 to remain quiescent. When tamoxifen was given at P6 and P7, inside the organ of Corti, iCre activity of $\mathrm{Fgfr} 3^{i \mathrm{CreER}+}$ were present in almost all IPCs, OPCs, and DCs (Cox et al., 2012). Again, only a few iCre + cells were OHCs, Hensen's cells and Claudius cells. 

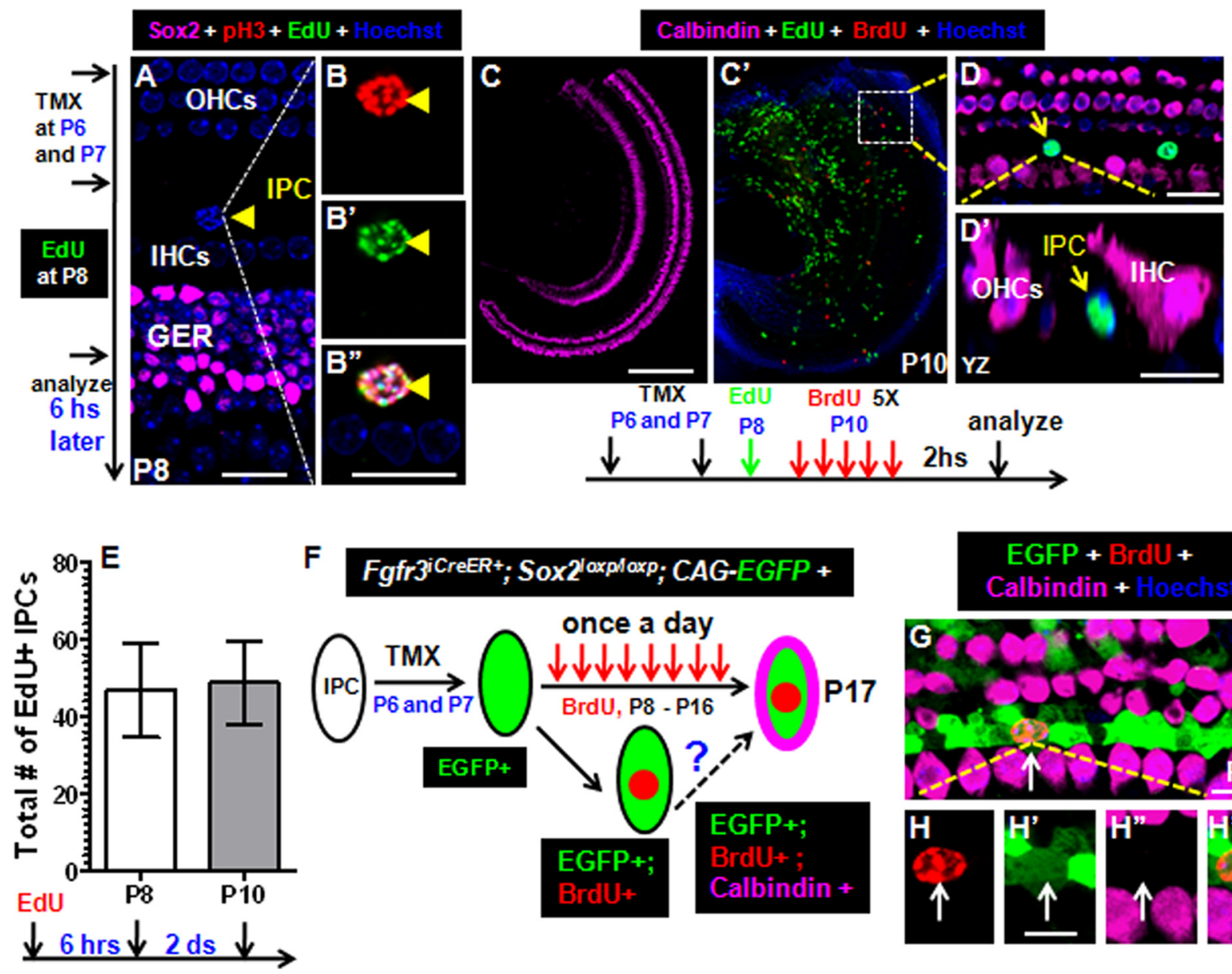

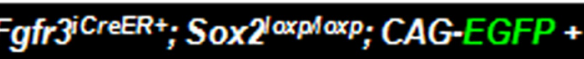

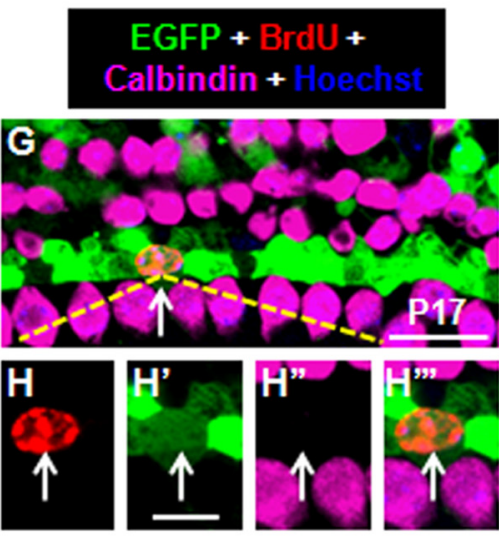

Figure 4. Sox2-negative IPCs in juvenile mice cannot complete the entire cell cycle and maintained a SC fate. $\boldsymbol{A}-\boldsymbol{B}^{\prime \prime}$, Triple staining of Sox2, pH3 and EdU in samples from Fgfr3 ${ }^{\text {icreeR }+}$; Sox2 ${ }^{\text {loxP/loxP }}$ experimental mice induced with tamoxifen at P6 and P7. Only Sox2 and nuclei labels were shown in $A$. Arrowheads point to the same mitotic IPC (EdU +/pH3 +/Sox2-negative) that migrated into the $\mathrm{HC}$ nuclei layer. $\boldsymbol{C}-\boldsymbol{D}^{\prime}$, Images were visualized at the $\mathrm{HC}$ layer $(\boldsymbol{C})$ and $\mathbf{S C}$ layer $\left(\boldsymbol{C}^{\prime}\right)$ of experimental samples. Arrows in $\boldsymbol{D}$ and $\boldsymbol{D}^{\prime}$ point to the same IPC, which is EdU +/BrdU-negative/calbindinnegative. $\boldsymbol{E}$, Quantification of EdU + IPCs in the entire cochlea of experimental samples that were given EdU at P8, and analyzed $6 \mathrm{~h}$ later or at P10. $\boldsymbol{F}$, Diagram of lineage tracing approach. $\mathbf{G}-\boldsymbol{H}^{\prime \prime \prime}$, Triple staining of EGFP, BrdU and calbindin in experimental samples. Arrows in $\mathbf{G}$ and $\left(\boldsymbol{H}-\boldsymbol{H}^{\prime \prime \prime}\right)$ point to the same IPC that was EGFP +/BrdU +/calbindin-negative. GER, Greater epithelial ridge. Scale bars: $\boldsymbol{A}, \boldsymbol{B}^{\prime \prime}, \mathbf{D}, \mathbf{G}, 20 \mu \mathrm{m} ; \boldsymbol{C}, 200 \mu \mathrm{m} ; \boldsymbol{H}^{\prime}, 10 \mu \mathrm{m}$.

Similar to the experimental design for neonatal ages, we used $F g f r 3^{i C r e E R+}$; Sox $2^{\text {loxPlloxP }}$ mice as the experimental group and $\mathrm{Fgfr}^{\text {iCreER+}}{ }^{\text {; }}$ Sox $2^{+/+}$mice as the control group. Both groups were treated with tamoxifen once a day at P6 and P7, EdU at P8 and analyzed $6 \mathrm{~h}$ later. Sox2 was expressed normally in IPCs, OPCs, and DCs in control mice (Fig. $3 A-A^{\prime \prime}$ ), but lost in many IPCs, OPCs, and DCs in experimental mice (Fig. $3 B-B^{\prime \prime}$ ). Consistently, no EdU + cells were observed inside the organ of Corti of control mice (Fig. $3 A-A^{\prime \prime}$ ). In contrast, scanning of the entire cochlea of experimental mice revealed $45 \pm 12(n=3)$ EdU + cells (all Sox2-negative) (Fig. $3 B-B^{\prime \prime}$ ). All EdU+ cells were IPCs, which were defined primarily according to their location and the unique structure of organ of Corti at P8 (Fig. 3C). These results demonstrate that only Sox2-negative IPCs reenter $S$ phase of the cell cycle. Among EdU+ IPCs, 34.3\% were distributed in apical turns, $37.2 \%$ in middle turns and $28.5 \%$ in basal turns. These numbers did not display the apical-to-basal gradient seen when Sox 2 was deleted at P0 and P1. Consistently, there was no longer an apical-to-basal gradient of Sox2-negative/p2 $7^{\text {Kip } 1}$-negative IPCs at P8 (Fig. 3D). It might be due to the overall lower level of p2 $7^{\text {Kip } 1}$ at P6/7 than P0/1, thus a shorter time delay between Sox 2 deletion and degradation of the endogenous $\mathrm{p} 27^{\mathrm{Kip} 1}$ below the detecting level. In addition, almost all IPCs lost Sox2 expression by P8 (Fig. 3D) and all EdU+ IPCs were p2 ${ }^{\text {Kip1 }}$-negative/Sox2negative (Fig. $3 E-E^{\prime \prime \prime}$, arrows). Again, Sox2-negative/p27 $7^{\text {Kip } 1}+$ IPCs were observed (Fig. $3 E-E^{\prime \prime \prime}$, arrowheads). Both Sox2+ and Sox2negative OPCs (Fig. $3 E-E^{\prime \prime \prime}$ ) and DCs continued to express p2 $7^{\text {Kip } 1}$, and we never observed EdU incorporation in these cell types.

We also found limited EdU $+/ \mathrm{pH} 3+/$ Sox2-negative IPCs at P8 ( $8 \pm 2$ in the whole cochlea, $n=3$ ) (Fig. $4 A-B^{\prime \prime}$ ), indicating that at least some Sox2-negative IPCs enter M phase of the cell cycle. However, EdU+/BrdU+ IPCs were not detected when EdU was given once at $\mathrm{P} 8$ and BrdU was given 5 times (at $2 \mathrm{~h}$ intervals) at P10 (Fig. $\left.4 C-D^{\prime}\right)$. In support, when EdU was given once at P8, there was no difference in the total number of EdU+ IPCs between P8 and P10 (Fig. 4E). These results suggest that Sox2-negative IPCs cannot complete the cell cycle and no new daughter cells were generated. Because we did not observe cells that were arrested at late M phase (or binucleated cells) at P10, the mitotic cells likely died between P8 and $\mathrm{P} 10$, as in the case of $\mathrm{Rb}^{-1-} \mathrm{HCs}$ that cannot complete mitosis (Weber et al., 2008). However, we cannot rule out the possibility that some Sox2-negative IPCs do divide once and the daughter cells die immediately. In addition, when BrdU was injected 5 times (at $2 \mathrm{~h}$ intervals) at P10, only $5 \pm 2(n=3) \mathrm{BrdU}+$ IPCs were found in the whole cochlea, further supporting the notion that most, if not all, Sox2-negative IPCs became quiescent by P10. 


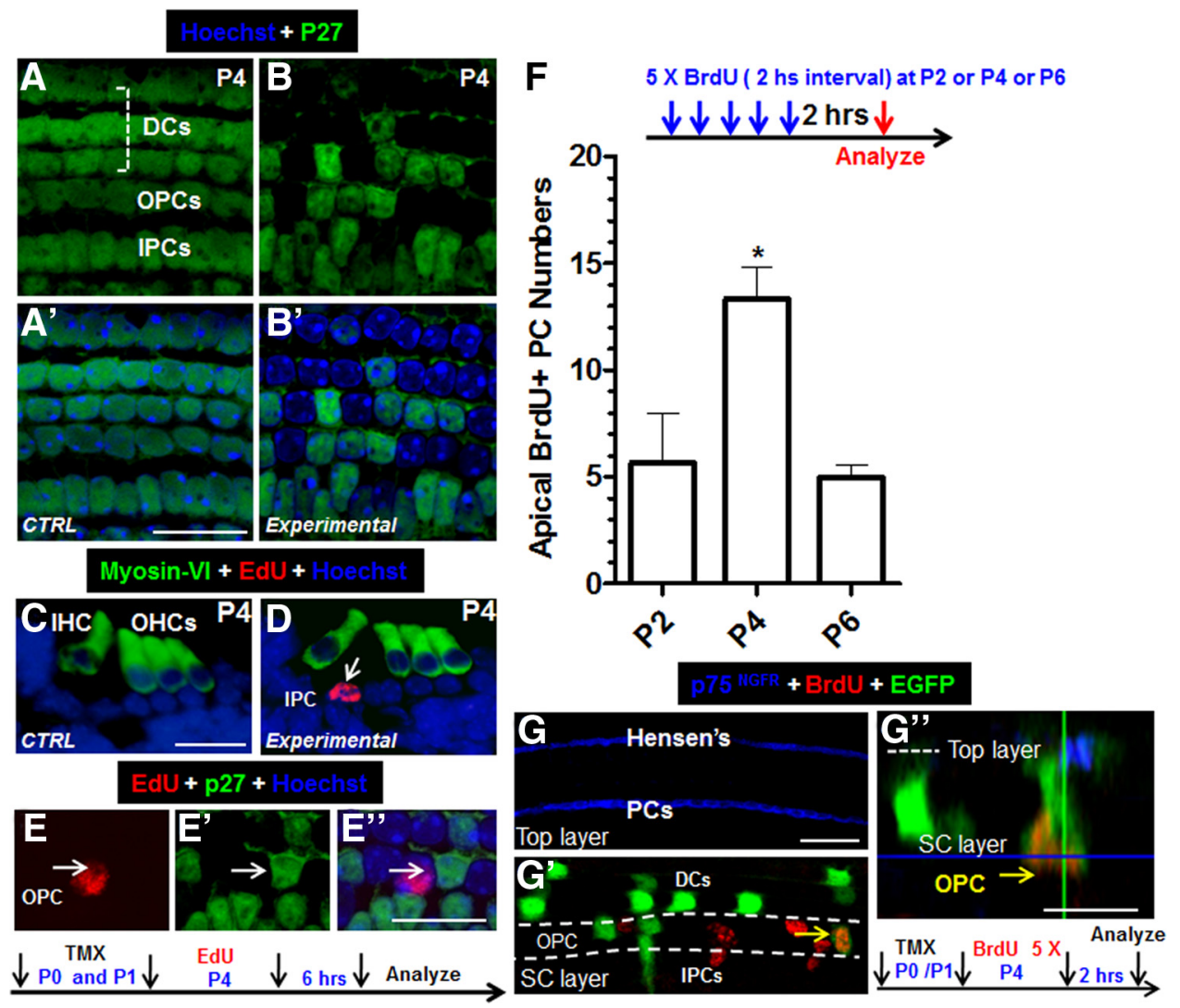

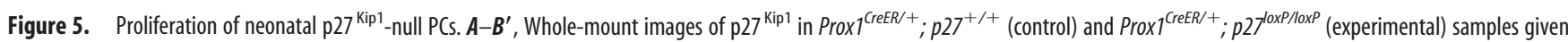
tamoxifen at P0 and P1. C, D, Artificial cross-section images of control $(\boldsymbol{C})$ and experimental (D) samples stained with myosin VI and EdU. $\boldsymbol{E}-\boldsymbol{E}^{\prime \prime}$, Double labeling of EdU and p27 ${ }^{\text {Kip } 1}$ in whole-mount

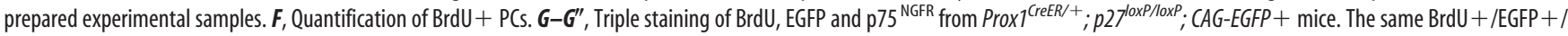
$\mathrm{p} 75^{\mathrm{NGFR}}+\mathrm{PC}$ was viewed in confocal XY plane (arrow in $\mathbf{G}^{\prime}$ ) and YZ plane (arrow in $\boldsymbol{G}^{\prime \prime}$ ). Scale bars, $20 \mu \mathrm{m} .{ }^{*} p<0.05$.

We performed lineage tracing experiments to determine whether these Sox2-negative SCs maintained a SC fate or switched to a $\mathrm{HC}$ fate. We could no longer use Prox 1 to define SC fate as we did with neonatal ages (Fig. $2 C-D^{\prime \prime \prime}$ ), because Prox1 is rapidly downregulated in SCs within the first week after birth, especially in IPCs (Bermingham-McDonogh et al., 2006). Fgfr $3^{\text {iCreER+ }}$; Sox $2^{\text {loxP/loxP }}$; CAG-EGFP+ mice were used as the experimental group and $\mathrm{Fgfr} 3^{\mathrm{iCreER+}}$; Sox $2^{+/+}$; CAG-EGFP+ as the control group. BrdU was given once a day from $\mathrm{P} 8$ to $\mathrm{P} 16$ and samples were analyzed at P17. Our standard to define a HC fate (if converted from proliferating IPCs) was the presence of BrdU+/ EGFP+/calbindin + cells (Fig. $4 F$ ). We did not find such triplepositive cells, and all BrdU + /EGFP + cells did not express the HC marker calbindin (Fig. 4G- $\left.H^{\prime \prime \prime}\right)$. Finally, consistent with the observation that iCre activity in $\mathrm{Fgfr} 3^{i \mathrm{CreER}+}$ mice was present in limited number of endogenous OHCs (Cox et al., 2012), a few EGFP+/calbindin + cells (endogenous HCs with iCre activity) were found in the experimental group. However, the number of EGFP +/calbindin + cells was similar between the experimental and control groups, suggesting that Sox2-negative OPCs and DCs also did not change fate to become HCs.

\section{Sox2 deletion in adult IPCs causes limited cell cycle reentry} without switching cell fate

Sox2 expression is maintained in adult SCs (Hume et al., 2007). To study the role of Sox 2 at adult ages, we deleted Sox2 in SCs at $\mathrm{P} 30$. When tamoxifen was given at P30, iCre activity were exclusively in SCs (Liu et al., 2012c). Fgfr ${ }^{i \text { CreER+ }}$; Sox $2^{\text {loxP/loxP }}$ (experimental group) and $\mathrm{Fgfr}^{\mathrm{iCreER+}} ; \mathrm{Sox}^{+/+}$(control group) were given tamoxifen once at P30, EdU at P32 and analyzed $6 \mathrm{~h}$ later. As expected, almost all PCs and DCs lost Sox2 expression (data not shown). No EdU + cells were observed inside the organ of Corti in control mice. However, only $5 \pm 3(n=3)$ EdU+/Sox 2 negative IPCs were found across the entire cochlea (data not shown). Adult IPCs could be defined as IPCs because they have well defined locations despite losing their oblong nuclear shape. The limited number of EdU+ IPCs prompted us to speculate whether adult Sox2-negative IPCs would need a longer time to reenter $S$ phase. Because adult mice can tolerate multiple EdU injections, we injected EdU at P34, P36, P38, and P40 and analyzed the cochleae $6 \mathrm{~h}$ later the last EdU injection (data not shown). Only $1 \pm 1(n=4)$ EdU $+/$ Sox2-negative IPC was found across the entire cochlea and no EdU+/Sox2-negative OPCs and DCs were observed. In addition, lineage tracing analysis with Fgfr $3^{\text {iCreER+ }}$; Sox $2^{\text {loxP/loxP }}$; Rosa26-CAG-tdTomato ${ }^{\text {loxP/+ }}$ mice did not reveal any tdTomato+/calbindin + cells at P50. Together, our results suggest that adult IPCs have a very limited capacity to proliferate after Sox 2 ablation and they maintain their intrinsic SC fate.

Deletion of $\mathrm{p} 27^{\mathrm{Kip} 1}$ leads to proliferation of neonatal, but not adult pillar cells without cell fate conversion

Our data suggest that repression of $p 27^{\text {Kipl }}$ by Sox 2 deletion primarily determines the proliferative state of IPCs. To further provide in vivo evidence of the epistatic interaction between Sox2 and $p 27^{\text {Kip } 1}$ and due to lack of an IPC-specific Cre driver, we conditionally deleted $p 27^{\text {Kipl }}$ in PCs and DCs by using the Prox $1^{\text {CreER/+ }}$; $p 27^{\text {loxP/loxP }}$ (experimental group) or Prox $1^{\mathrm{CreER} /+} ; \mathrm{p}^{27^{+/+}}$(control group) mice. We used Prox $1^{\mathrm{CreER} /+}$ instead of $\mathrm{Fg} f \mathrm{r} 3^{\mathrm{iCreER+}}$ 
mice to take advantage of their specific Cre activity in PCs and DCs (Yu et al., 2010).

Both groups were given tamoxifen once a day at P0 and P1, EdU at P4 and analyzed $6 \mathrm{~h}$ later. $\mathrm{p} 27^{\mathrm{Kip} 1}$ was expressed normally in control mice (Fig. 5A, $A^{\prime}$ ), while many PCs and DCs in experimental mice lost p27 ${ }^{\text {Kip } 1}$ expression (Fig. $5 B, B^{\prime}$ ). Consistently, while no EdU+ cells were found inside the organ of Corti in control mice (Fig. 5C), EdU + cells were present in experimental mice (Fig. 5D). We focused on the apical turn where Cre activity was the highest (Yu et al., 2010). Strikingly, all EdU + cells were either IPCs or OPCs (Fig. $5 D, E^{\prime \prime}$ ) and were p2 $7^{\mathrm{Kip} 1}$ negative (Fig. $5 E-E^{\prime \prime}$ ). Because of the low Cre activity of Prox $1^{\mathrm{CreER} /+}$, the number of EdU + PCs was limited. Since multiple EdU injections are lethal to neonates, we performed BrdU labeling (injection 5 times at 2 h intervals) at P2, P4 or P6 and analyzed $2 \mathrm{~h}$ after the last BrdU injection to label more proliferating cells. To minimize the variation caused by the apical-tobasal gradient of Cre activity, we analyzed the same $200 \mu \mathrm{m}$ length in the apical turn ( $\sim 1500 \mu \mathrm{m}$ from the most apical tip). There were $5 \pm 3(n=3)$ BrdU + PCs at $\mathrm{P} 2,13 \pm 2(n=3) \mathrm{BrdU}+\mathrm{PCs}$ at $\mathrm{P} 4$, and $5 \pm 1(n=3) \mathrm{BrdU}+\mathrm{PCs}$ at P6 (Fig. $5 F)$, suggesting that proliferation of $\mathrm{PCs}$ started at $\mathrm{P} 2$, peaked at $\mathrm{P} 4$ and declined at P6. Again, all BrdU+ cells were PCs, estimated based on location.

To confirm that proliferating cells were PCs, we stained for $\mathrm{p} 75^{\mathrm{NGFR}}$, which is expressed on the cell surface of PCs and Hensen's cells but not DCs (White et al., 2006) (Fig. 5G). Prox $1^{\mathrm{CreER} /+} ;$ p $27^{\operatorname{lox} P / \operatorname{lox} P}$; $C A G-E G F P+$ mice were given BrdU 5 times (at $2 \mathrm{~h}$ intervals) at $\mathrm{P} 4$ and samples were immunostained with $\mathrm{p} 75^{\mathrm{NGFR}}$, BrdU and EGFP. The entire cell body was traced with EGFP, making it easy to determine whether $\mathrm{p} 75^{\mathrm{NGFR}}$ (expressed on the cell surface) and BrdU (expressed in the nucleus) belong to the same cell. All $25 \mathrm{BrdU}+/ \mathrm{EGFP}+$ cells analyzed were also p75 ${ }^{\mathrm{NGFR}}+$ (Fig. $\left.5 G^{\prime}, G^{\prime \prime}\right)$.

We frequently observed $\mathrm{pH} 3+\mathrm{PCs}$ distributed in the $\mathrm{HC}$ layer between the inner most row of OHCs and IHCs (Fig. 6A). We also found $2 \pm 1(n=3) \mathrm{pH} 3+$ PCs in either metaphase (Fig. $6 B$ ) or anaphase (Fig. 6C). To determine whether neonatal p2 ${ }^{\text {Kip1 }}$-negative PCs can complete the cell cycle and give rise to new daughter cells, we injected BrdU 5 times (at $2 \mathrm{~h}$ intervals) at $\mathrm{P} 2$ followed by one EdU injection at P4. We found BrdU+/ EdU + PCs (Fig. 6D), suggesting that p27 ${ }^{\mathrm{Kip} 1}$-PCs incorporated BrdU at P2 generate new daughter cells that were then able to reenter $\mathrm{S}$ phase and incorporate EdU at P4. We observed $30 \pm 5$ $(n=3) \mathrm{BrdU}+/ \mathrm{EdU}+\mathrm{PC}$ in each sample. In all samples, there was an increase in the total number of PCs, but not DCs (Fig. $6 E, F)$. Together, our results suggest that deleting $\mathrm{p} 27^{\mathrm{Kip} 1}$ causes PCs to reenter the cell cycle and generate new daughter cells.

The p $27^{\text {Kip } 1}$-negative PCs and DCs also maintained expression of Sox2 (Fig. $7 A-A^{\prime \prime \prime}$ ) and Prox1 (Fig. $7 B-B^{\prime \prime \prime}$ ), suggesting that they retained a SC fate. We also performed lineage tracing studies by analyzing Prox $1^{\mathrm{CreER} /+} ;$ p $27^{\text {loxP/loxP }}$; CAG-EGFP+ mice. No EGFP+/myosin VI+ cells were identified at P6, P10 or $\mathrm{P} 15$. Together, our data demonstrate that $\mathrm{p} 27^{\mathrm{Kip} 1}$-negative PCs do not convert into HCs.

Because $\mathrm{p} 27^{\mathrm{Kip} 1}$ expression is maintained in adult SCs (Löwenheim et al., 1999; Laine et al., 2010), we also deleted $\mathrm{p} 27^{\mathrm{Kip} 1}$ in adult PCs at P30. Prox $1^{\mathrm{CreER} /+}$ cannot be used because Prox1 becomes undetectable before P30 (BerminghamMcDonogh et al., 2006). Instead, we used Fgfr $3^{i \text { CreER+ }} ; p 27^{\text {loxP/loxP }}$ (experimental group) and Fgfr ${ }^{i C r e E R+} ; p 27^{+/+}$(control group) mice given tamoxifen once at P30; EdU once each at P32, P33, P34; and analyzed at P35. No EdU + cells were found inside the organ of Corti of control mice and only a very limited number of EdU $+/$ Sox $2+$ cells $(4 \pm 2, n=3$ ) (believed to be PCs based on location) were observed in experimental mice (data not shown). This observation verifies that adult PCs have limited proliferative capacity.

\section{Functional consequences due to inducible loss of Sox 2 or} p2 $7^{\text {Kip1 }}$ in the mouse cochlea

We examined the long-term effect of the conditional loss of Sox 2 at P0 and P1, because the most significant cellular proliferation was observed at neonatal ages. We found significant $\mathrm{HC}$ loss in cochlear samples of experimental, but not control 


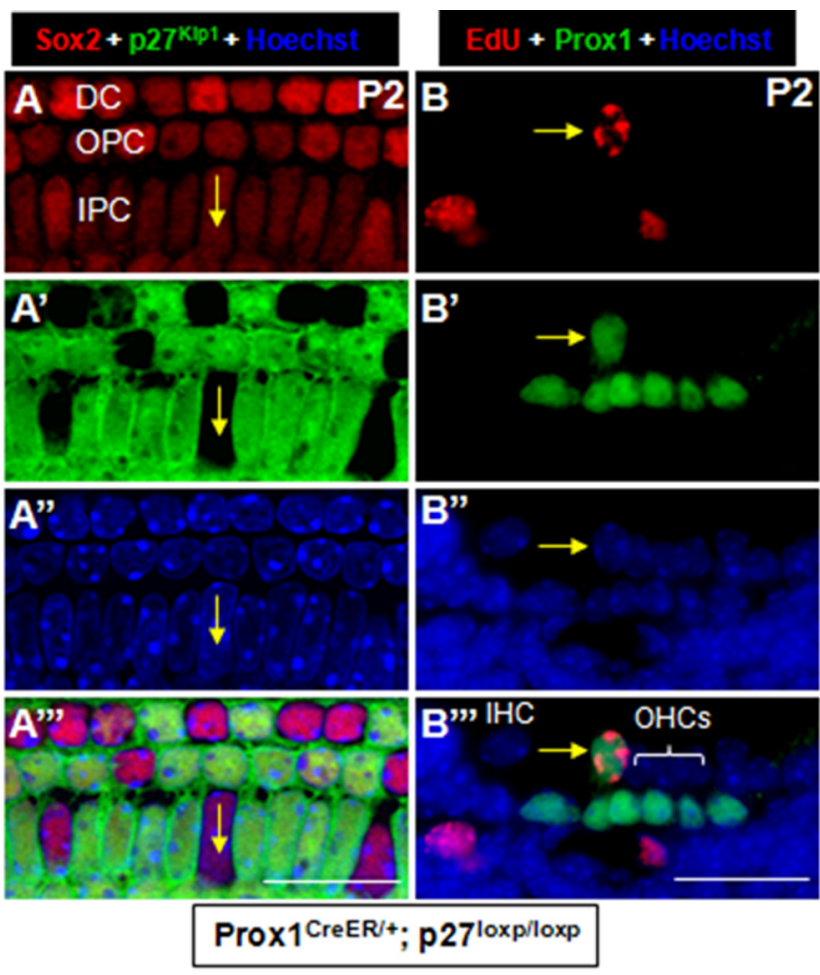

Figure 7. Proliferating $\mathrm{p} 27^{\mathrm{Kip} 1}$-null PCs maintain Prox 1 and Sox2 expression. $A-A^{\prime \prime \prime}$, Double labeling of Sox2 and p27 $7^{\text {Kip } 1}$ at P2 in Prox $7^{\text {CreeR/+ }} ; p 27^{\text {loxP/loxP }}$ (experimental) samples given tamoxifen at $\mathrm{PO}$ and $\mathrm{P} 1$. Arrows point to the same Sox2 +/p27 Kip1-negative IPC. $\boldsymbol{B}-\boldsymbol{B}^{\prime \prime \prime}$, Crosssection staining of EdU and Prox1 at P2. Arrows point to the same Prox1 + / EdU + PC. Similar results were observed at $\mathrm{P} 4$. Scale bars, $20 \mu \mathrm{m}$. mice at P16 (Fig. $8 A-C$ ). The majority of the lost HCs were OHCs (Fig. $8 B, C$ ), while small fractions were IHCs (Fig. $8 B^{\prime}$, arrow), which was further confirmed by TUNEL staining (Fig. $\left.8 D-D^{\prime}\right)$. In addition, more HCs were lost in the apical turn than in middle or basal turns (Fig. $8 A-C$ ). Similarly, we also analyzed the Prox $1^{\mathrm{CreER} /+} ;$ p $27^{\text {loxP/loxP }}$ mice that were given tamoxifen at P0/P1. While all OHCs were intact at P10, sporadic $\mathrm{OHC}$ loss was found at $\mathrm{P} 15$. TUNEL + cells were identified at P15, supporting the idea that cell death happened gradually (data not shown).

Our data do not necessarily mean that Sox 2 or $\mathrm{p} 27^{\text {Kip } 1}$ has a direct role in cell survival. We believe that cell death is a secondary effect caused by aberrant cell proliferation in the cochlea which has been observed in other models where deletion of cell cycle inhibitors such as Rb or p19 ${ }^{\text {Ink4d }}$ also eventually causes cell death (Chen et al., 2003; Sage et al., 2006; Liu and Zuo, 2008; Yu et al., 2010). We did not find obvious neuronal phenotypes by $\mathrm{P} 22$ by quantifying calbindin + spiral ganglion neurons in whole-mount prepared cochlear samples of Fgfr $3^{i \mathrm{CreER}^{+}}$; Sox $2^{\text {loxP/loxP }}$ that were given tamoxifen at P0 and P1 (data not shown).

\section{Overexpression of Sox 2 results in activation of the $p 27^{\text {Kip } 1}$} promoter in vitro

To provide further evidence that Sox 2 can modulate the cisregulatory element of the $p 27^{K i p 1}$ promoter we used a construct in which luciferase is driven by the $p 27^{K i p 1}$ promoter $3.8 \mathrm{~kb}$ upstream of its transcription start site (Minami et al., 1997). We then performed transfections with this construct (Fig. 9A), along with an internal control of $L a c Z$ and either E2F1 (a known positive regulator of the $p 27^{\text {Kip } 1}$ promoter (Wang et al., 2005), Sox2 or an empty vector. Because Sox 2 binding has been shown to be dependent on distinct binding partners in
CTRL
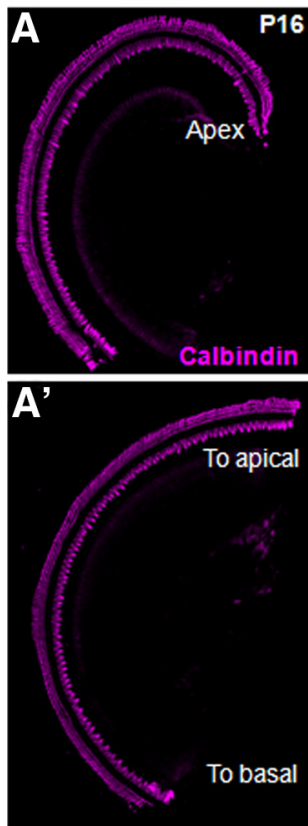

TMX P0 and P1

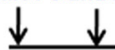

Experimental
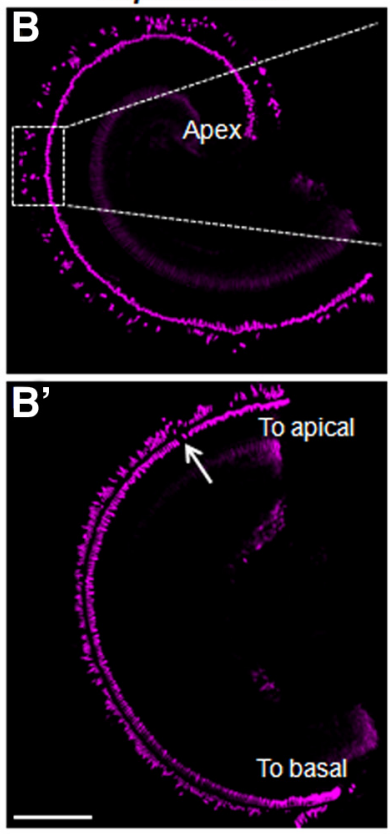

Analyze P16

\section{Calbindin}

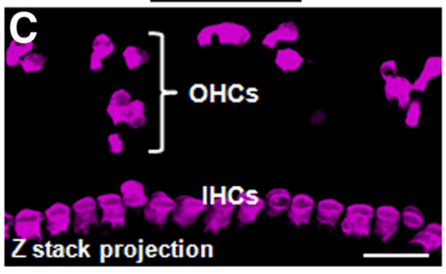

TUNEL + Calbindin

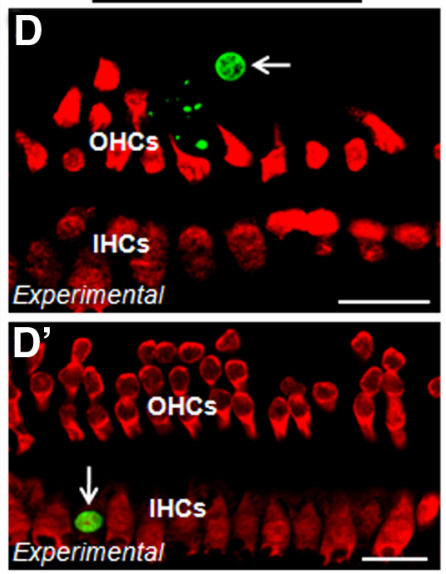

Figure 8. Long-term effects caused by proliferation of neonatal IPCS. $\boldsymbol{A}-\boldsymbol{B}^{\prime}$, Whole-mount image of calbindin $+\mathrm{HCS}$ in $\mathrm{Fgfr}^{\text {iCreER }}{ }^{+} ;$Sox $2^{+/+} \operatorname{control}\left(\boldsymbol{A}, \boldsymbol{A}^{\prime}\right)$ and Fgfr $3^{i \text { (reER+ }} ;$ Sox $2^{\text {loxP/loxP }}$ experimental $\left(\boldsymbol{B}, \boldsymbol{B}^{\prime}\right)$ groups. Arrow in $\boldsymbol{B}^{\prime}$ indicates 3 missed IHCs. C, Projection image of the rectangular area in $\boldsymbol{B}$ showing loss of $\mathrm{OHCS.} \boldsymbol{D}, \boldsymbol{D}^{\prime}$, Image of TUNEL and calbindin labeling in experimental mice at P16. Arrows indicate dying cells. Scale bars: $\boldsymbol{B}^{\prime}, 200 \mu \mathrm{m} ; \boldsymbol{C}-\boldsymbol{D}^{\prime}, 20 \mu \mathrm{m}$. different cell types (Kamachi et al., 2000), we examined the effects of Sox2 overexpression in 3 cell types: MEF cells, HeLa cells, and HEK cells. When transfections were performed on all 3 cell types, we found that overexpression of E2F1 resulted in upregulation of luciferase, as measured by luciferase activity (Fig. $9 B-D, n=3)$. Overexpression of Sox 2 led to significant upregulation of luciferase in both MEF and HeLa cells (Fig. 9 B, C), but had no significant effect on HEK cells (Fig. 9D). Luciferase luminosity was normalized to $\beta$-galactosidase luminosity to account for any changes due to cell viability, cell number or transfection efficiency. When the $p 27^{\text {Kip } 1}$ promoter was removed from the vector, minimal luciferase was observed, with no regulation due to overexpression of Sox 2 or E2F1 (Fig. $9 B-D$, $n=3)$.

\section{Sox 2 binds the $p 27^{K i p 1}$ promoter in vitro}

Activation of the p $27^{\text {Kip1 }}$-luciferase plasmid by overexpression of Sox 2 demonstrates that both Sox 2 and $\mathrm{p} 27^{\mathrm{Kip} 1}$ are potentially in the same pathway, but it is unclear whether it is a direct activation of $\mathrm{p} 27^{\text {Kip } 1}$ by Sox 2 or whether Sox 2 is func- 
tioning indirectly to activate the $p 27^{\text {Kip } 1}$ promoter. To distinguish these possibilities, we created 9 primer pairs which contiguously cover $\sim 2 \mathrm{~kb}$ of the promoter region directly upstream of the luficerase open reading frame (ORF) (Fig. 9E). Since there are a very limited number of IPCs in the cochlea, we could not measure this interaction in vivo. Instead, we performed ChIP under the same conditions used for the luciferase experiments (Fig. $9 B-D)$, and observed a significant enrichment of the region $\sim 1400$ bp upstream of the luciferase ORF (amplicon \#7) when the Sox2 antibody was used (Fig. 9F, $n=3$ ). These data are displayed as enrichment over background $\left(2^{\left(C_{\mathrm{t}} \text { Sox2 }\right)-\left(C_{\mathrm{t}} \mathrm{IgG}\right)}\right)$, which is then normalized to the nonspecific amplicon to account for any nonspecific binding of the Sox 2 antibody.

The ChIP data presented here, combined with the luciferase reporter assays, and the in vivo epistatic interaction, suggest that Sox 2 is able to act in cis to control expression of $p 27^{K i p 1}$. Such regulation is cell content dependent as it occurs only in IPC but not OPC/DC in vivo, and in MEF/ HeLa but not HEK cells in vitro. However, we cannot rule out the possibility that Sox 2 can also regulate $p 27^{K i p 1}$ in an indirect manner.

\section{Discussion}

In this study, we demonstrate that Sox2 maintains the quiescent state of neonatal and juvenile IPCs by maintaining $p 27^{\text {Kip } 1}$ expression (summarized in Fig. 10). In addition, luciferase reporter and Sox2ChIP assays demonstrate that Sox 2 is an activator of the $p 27^{K i p 1}$ promoter and Sox 2 can interact with cis-regulatory regions of $p 27^{K i p 1}$. Our data also show that this signaling cascade occurs in an agedependent manner.

\section{A novel role of Sox 2 in neonatal and juvenile cochlear IPCs}

Sox2 is a transcription factor that carries a DNA-binding high-mobility group (HMG) domain and affects gene transcription through collaboration with different partners that are specific to cell type or age (Kamachi et al., 2000). In many mouse embryonic tissues such as the retina, Sox 2 is highly expressed in proliferating progenitors and loss of Sox 2 leads to defective proliferation (Taranova et al., 2006). This suggests a general role of Sox 2 to promote proliferation in embryonic cells, which might explain the severe defect in inner ear development in the two Sox2 hypomorphic mouse models (Kiernan et al., 2005).

Sox2 also antagonizes Atoh1, which is a transcription factor crucial for HC development (Dabdoub et al., 2008). Because Sox2 is highly expressed in postnatal SCs (Hume et al., 2007; Oesterle
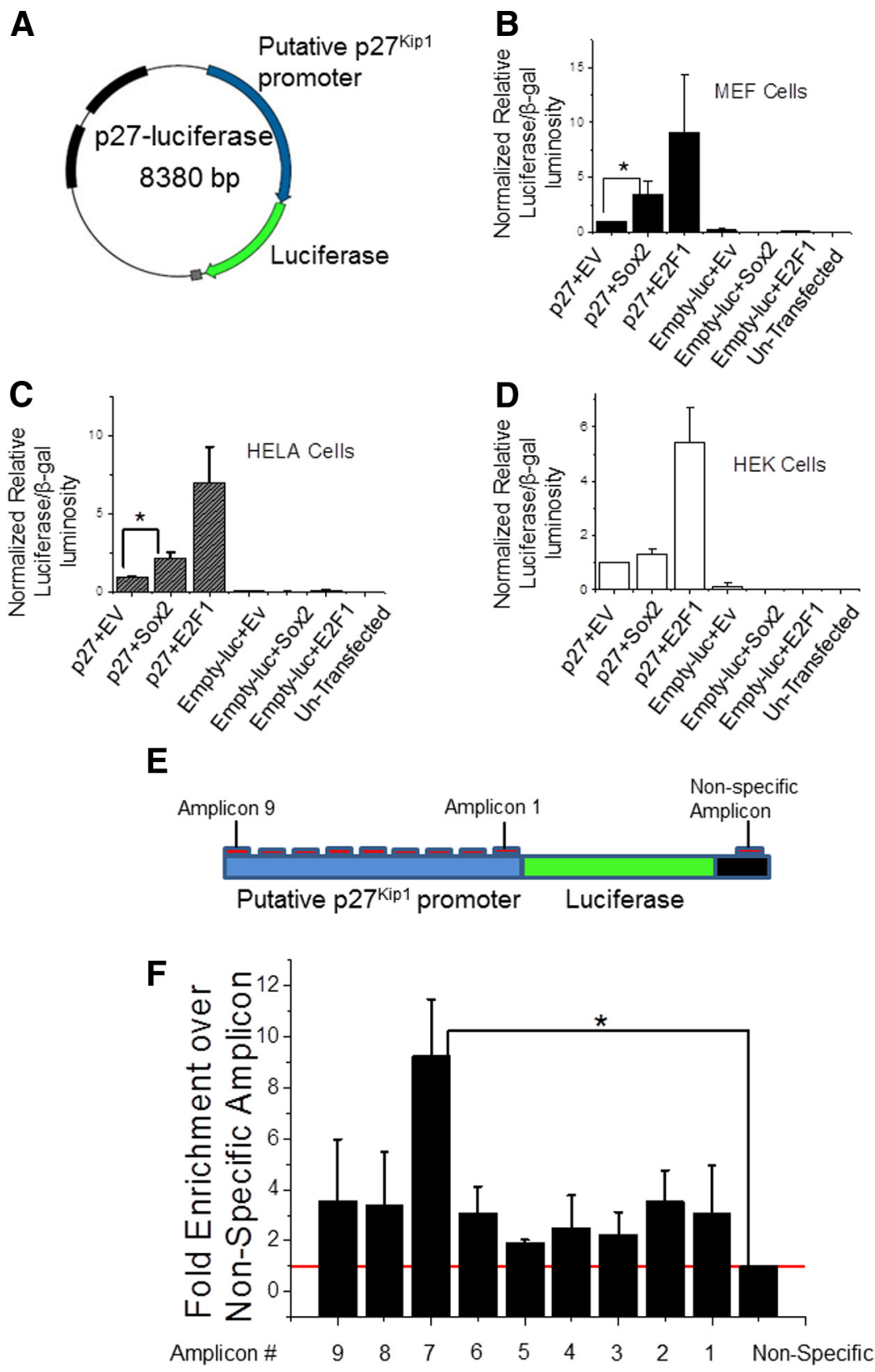

Figure 9. Sox2 regulates $\mathrm{p} 27^{\mathrm{Kip} 1}$ in vitro. $A$, Schematic of the luciferase construct used in the reporter assay. The blue region is a $3.8 \mathrm{~kb}$ putative $p 27^{k i p 1}$ promoter fragment. $\boldsymbol{B}-\boldsymbol{D}$, The effect of Sox2 overexpression on $p 27^{\text {Kip } 1}$ transcriptional activity was measured in MEF $(\boldsymbol{B})$, HeLa $(\boldsymbol{C})$, and HEK cells $(\boldsymbol{D})$. All values were normalized to the negative control empty vector (EV), then compared with the positive control E2F1, or Sox2 overexpression. Minimal luciferase activity was detected when a promoter-less luciferase vector was used (empty-luc), with no increases occurring in the presence of Sox2 or E2F1. E, Schematic of the p27Iuciferase plasmid and amplicon location. $\boldsymbol{F}$, qPCR data from ChIP experiments performed in MEF cells transfected with p27luciferase plasmid and Sox2. A significant enrichment of amplicon 7 ( $\sim 1400$ bp upstream of Luciferase ORF) was observed when the Sox2 antibody was used for ChIP. ${ }^{*} p<0.05$. et al., 2008), we first hypothesized that Sox2 maintains SC fate and predicted that Sox 2 deletion would cause a conversion of SCs into HCs. However, our data do not support this hypothesis and suggest that Sox 2 is dispensable for SC fate maintenance.

In contrast, deletion of Sox 2 specifically in postnatal cochlear SCs shows that Sox2 keeps neonatal and juvenile IPCs quiescent by maintaining expression of $\mathrm{p} 27^{\mathrm{Kip} 1}$. This novel role of Sox 2 in regulating its target $p 27^{\text {Kip } 1}$ may be important for other tissues and cell types as well. Of note, Sox2-negative/p2 $7^{\text {Kip1 }}+$ IPCs were present (Figs. $2 B-B^{\prime \prime \prime}, 3 E-E^{\prime \prime \prime}$ ). We have 2 speculations: (1) it is 


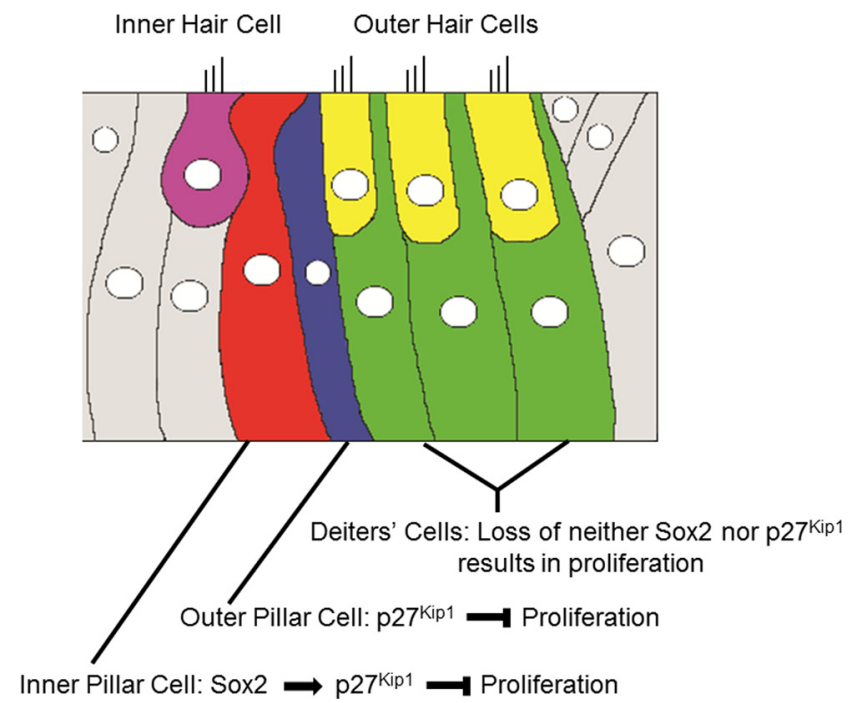

Figure 10. Proposed model of heterogeneous cell cycle regulation in different supporting cell subtypes. The Sox2-p2 $7^{K i p 1}$ signaling pathway maintains the quiescent state of inner pillar cells (red). p27 ${ }^{\text {Kip } 1}$ itself is needed to keep outer pillar cells (blue) quiescent, whereas the identity of the upstream regulator is unclear. Neither Sox 2 nor $p 27^{\text {Kip } 1}$ is necessary to maintain the quiescence of Deiters' cells (green).

due to the fact that different IPCs require different amounts of time to degrade the endogenous $\mathrm{p} 27^{\text {Kip } 1}$ present before Sox 2 ablation occurred, which would explain the Sox2-negative/ p2 $7^{\text {Kip } 1}+$ IPCs; (2) it is also possible that Sox2 is one of many factors needed to keep IPCs quiescent, and this heterogeneity underlies our observation.

Our data demonstrate that Sox 2 is dispensable for expression of $\mathrm{p} 27^{\mathrm{Kip} 1}$ in OPCs and DCs. We also did not find Sox2dependent $p 27^{K i p 1}$ regulation in HEK cells, implying that this cell type does not express the appropriate binding partners needed for Sox 2 to regulate $p 27^{K i p 1}$. Therefore, it is possible that like HEK cells, OPCs, and DCs lack the Sox2-binding partners needed for interaction with $p 27^{K i p 1}$, whereas IPCs, MEF and HeLa cells retain them, allowing Sox2-dependent $p 27^{K i p 1}$ expression. Alternatively, other Sox family members such as Sox9 (Mak et al., 2009) and Sox 10 (Breuskin et al., 2009) may compensate for Sox2 ablation in OPCs and DCs. Finally, adult Sox2-negative IPCs showed limited proliferation, reflecting an age-dependent shift away from the Sox2-p2 $7^{K i p l}$ pathway, potentially through a shift in Sox2-binding partners available within IPCs.

We attempted to use Plp ${ }^{\text {CreER+ }}$ (Gómez-Casati et al., 2010) mouse line to delete Sox2 in the IPHs. Unfortunately, for reasons not clear, it is difficult to get progeny by crossing $\mathrm{Pl}^{\mathrm{CreER}+}$; Sox $2^{\text {loxP/+ }}$ with Sox $2^{\text {loxP/+ }}$ mice. Therefore, it remains to be determined whether Sox2 is required to keep postnatal IPHs quiescent. It is also unclear whether Sox 2 is required to maintain quiescence of mouse vestibular SCs. Addressing this issue is difficult because iCre activity of Fgfr $3^{\text {iCreER }}$ was absent in vestibular SCs (data not shown) and is beyond the focus and scope of our study here.

\section{Roles of $\mathrm{p} 27^{\text {Kip } 1}$ during mouse cochlear development}

The role of $\mathrm{p} 27^{\text {Kip } 1}$ in driving cochlear progenitors to exit the cell cycle has been well established (Chen and Segil, 1999; Löwenheim et al., 1999). By deleting $p 27^{K i p 1}$ in PCs and DCs at P0 and P1, we found that only p2 ${ }^{\text {Kip } 1}$-negative PCs (both IPCs and OPCs) could proliferate, complementary to the study where neonatal cochlear SCs (mostly cells in the lesser epithelial ridge) were tar- geted by viruses expressing $p 27^{K i p 1}$-shRNA resulting in proliferation and production of daughter cells (Ono et al., 2009). Recently, $C A G^{\text {CreER+ }} ; p 27^{\text {loxP/loxP }}$ mice were used to delete $p 27^{\text {Kipl }}$ in many cell types, including cochlear SCs; this study demonstrated that neonatal PCs but not DCs reentered S phase of the cell cycle (Oesterle et al., 2011).

We found limited proliferation of adult PCs (but not DCs) when $p 27^{\text {Kip } 1}$ was deleted in our $F g f r 3^{\text {iCreER+ }} ; p 27^{\text {loxPlloxP }}$ model, but significant proliferation of "adult" DCs occurred in $C A G^{\text {CreeR+ }} ; p 27^{\text {loxP/loxP }}$ mice (Oesterle et al., 2011). We thought the difference might be explained by the occurrence of CreER leakage (i.e., active Cre without tamoxifen induction) in $C A G^{\text {CreER+ }}$ mice which was reported to occur after the first week (Oesterle et al., 2011); thus the proliferative "DCs" might actually be PCs that migrated to region of inner most row of DCs when samples were analyzed at 6 weeks (Oesterle et al., 2011).

\section{Decline in the proliferative capacity of postnatal cochlear SCs with age}

Our current study of Sox2 and p27 $7^{\text {Kip } 1}$ deletion and previous studies of Rb ablation in SCs at different postnatal ages (Yu et al., 2010; Huang et al., 2011) together support that the intrinsic proliferative capacity of postnatal IPCs declines as development proceeds. It is possible that adult SCs, even in the absence of cell cycle inhibitors, lack expression of cell cycle-positive regulators such as cyclin D1. In line with this explanation, neonatal SCs have higher expression of cyclin D1 than adult SCs, and interestingly PCs have higher cyclin D1 expression than DCs at neonatal ages (Laine et al., 2010). This might explain why p $27^{\text {Kipl }}{ }^{-}$-negative, neonatal DCs could not proliferate. Furthermore, overexpression of cyclin D1 in adult utricle SCs significantly increased their proliferative capacity in vitro (Loponen et al., 2011). Cyclin D1 overactivation in adult cochlear SCs may also lead to increased proliferation, but this has not been tested.

\section{Modulation of Sox 2 and p2 ${ }^{\text {Kip1 }}$ for mammalian hair cell regeneration}

When HC damage occurs in non-mammalian vertebrates such as birds, fish and amphibians, surrounding SCs proliferate and trans-differentiate into HCs, through which their hearing capacity is recovered. Decreased proliferation of SCs in the Phoenix mutant zebrafish leads to defective $\mathrm{HC}$ regeneration (Behra et al., 2009), which further highlights the importance of SC proliferation. However, in mammals, SCs are strictly kept quiescent even after HC damage, which might account for the inability of mammals to regenerate HCs.

Therefore, driving SCs to proliferate could be a necessary step in restoring the competence of regenerating $\mathrm{HCs}$ after damage in mammals. Our data suggest that the development of inhibitors of either Sox2 (for IPCs) or p27 ${ }^{\mathrm{Kip} 1}$ (for IPCs and OPCs) would allow neonatal SCs to proliferate and with proper delivery of these inhibitors, such treatment could have specific effects on inner ear cochlear SCs.

In summary, our in vivo epistatic genetic studies reveal that Sox 2 can act as an upstream activator of $p 27^{K i p 1}$ and that the Sox $2-p 27^{K i p 1}$ pathway helps to keep neonatal and juvenile IPCs quiescent. Because our current data demonstrate that proliferative PCs keep their intrinsic SC fate, we propose that additional steps (e.g., activation of Atoh1) are needed to direct daughter cells to undergo HC fate commitment and differentiation to achieve hearing regeneration in mammals. 


\section{References}

Behra M, Bradsher J, Sougrat R, Gallardo V, Allende ML, Burgess SM (2009) Phoenix is required for mechanosensory hair cell regeneration in the zebrafish lateral line. PLoS Genet 5:e1000455.

Bermingham NA, Hassan BA, Price SD, Vollrath MA, Ben-Arie N, Eatock RA, Bellen HJ, Lysakowski A, Zoghbi HY (1999) Math1: an essential gene for the generation of inner ear hair cells. Science 284:1837-1841.

Bermingham-McDonogh O, Oesterle EC, Stone JS, Hume CR, Huynh HM, Hayashi T (2006) Expression of Proxl during mouse cochlear development. J Comp Neurol 496:172-186.

Breuskin I, Bodson M, Thelen N, Thiry M, Borgs L, Nguyen L, Lefebvre PP, Malgrange B (2009) Sox10 promotes the survival of cochlear progenitors during the establishment of the organ of Corti. Dev Biol 335:327-339.

Brigande JV, Heller S (2009) Quo vadis, hair cell regeneration? Nat Neurosci 12:679-685.

Chen P, Segil N (1999) p27(Kip1) links cell proliferation to morphogenesis in the developing organ of Corti. Development 126:1581-1590.

Chen P, Zindy F, Abdala C, Liu F, Li X, Roussel MF, Segil N (2003) Progressive hearing loss in mice lacking the cyclin-dependent kinase inhibitor Ink4d. Nat Cell Biol 5:422-426.

Chien WM, Rabin S, Macias E, Miliani de Marval PL, Garrison K, Orthel J, Rodriguez-Puebla M, Fero ML (2006) Genetic mosaics reveal both cellautonomous and cell-nonautonomous function of murine p27Kip1. Proc Natl Acad Sci U S A 103:4122-4127.

Cox BC, Liu Z, Lagarde MM, Zuo J (2012) Conditional gene expression in the mouse inner ear using Cre-loxP. J Assoc Res Otolaryngol 13:295-322.

Dabdoub A, Puligilla C, Jones JM, Fritzsch B, Cheah KS, Pevny LH, Kelley MW (2008) Sox2 signaling in prosensory domain specification and subsequent hair cell differentiation in the developing cochlea. Proc Natl Acad Sci U S A 105:18396-18401.

Gómez-Casati ME, Murtie J, Taylor B, Corfas G (2010) Cell-specific inducible gene recombination in postnatal inner ear supporting cells and glia. J Assoc Res Otolaryngol 11:19-26.

Huang M, Sage C, Tang Y, Lee SG, Petrillo M, Hinds PW, Chen ZY (2011) Overlapping and distinct $\mathrm{pRb}$ pathways in the mammalian auditory and vestibular organs. Cell Cycle 10:337-351.

Hume CR, Bratt DL, Oesterle EC (2007) Expression of LHX3 and SOX2 during mouse inner ear development. Gene Expr Patterns 7:798-807.

Kamachi Y, Uchikawa M, Kondoh H (2000) Pairing SOX off: with partners in the regulation of embryonic development. Trends Genet 16:182-187.

Kiernan AE, Pelling AL, Leung KK, Tang AS, Bell DM, Tease C, Lovell-Badge $\mathrm{R}$, Steel KP, Cheah KS (2005) Sox2 is required for sensory organ development in the mammalian inner ear. Nature 434:1031-1035.

Laine H, Sulg M, Kirjavainen A, Pirvola U (2010) Cell cycle regulation in the inner ear sensory epithelia: role of cyclin D1 and cyclin-dependent kinase inhibitors. Dev Biol 337:134-146.

Lanford PJ, Lan Y, Jiang R, Lindsell C, Weinmaster G, Gridley T, Kelley MW (1999) Notch signalling pathway mediates hair cell development in mammalian cochlea. Nat Genet 21:289-292.

Lee YS, Liu F, Segil N (2006) A morphogenetic wave of p27Kip1 transcription directs cell cycle exit during organ of Corti development. Development 133:2817-2826.

Liu Z, Zuo J (2008) Cell cycle regulation in hair cell development and regeneration in the mouse cochlea. Cell Cycle 7:2129-2133.

Liu Z, Owen T, Zhang L, Zuo J (2010) Dynamic expression pattern of Sonic hedgehog in developing cochlear spiral ganglion neurons. Dev Dyn 239:1674-1683.

Liu Z, Owen T, Fang J, Zuo J (2012a) Overactivation of Notch1 signaling induces ectopic hair cells in the mouse inner ear in an age-dependent manner. PLoS One 7:e34123.

Liu Z, Owen T, Fang J, Srinivasan RS, Zuo J (2012b) In vivo Notch reactivation in differentiating cochlear hair cells induces Sox 2 and Proxl expression but does not disrupt hair cell maturation. Dev Dyn 241:684-696.
Liu Z, Dearman JA, Cox BC, Walters BJ, Zhang L, Ayrault O, Zindy F, Gan L, Roussel MF, Zuo J (2012c) Age-dependent in vivo conversion of mouse cochlear pillar and Deiters' cells to immature hair cells by atoh1 ectopic expression. J Neurosci 32:6600-6610.

Loponen H, Ylikoski J, Albrecht JH, Pirvola U (2011) Restrictions in cell cycle progression of adult vestibular supporting cells in response to ectopic cyclin $\mathrm{d} 1$ expression. PLoS One 6:e27360.

Löwenheim H, Furness DN, Kil J, Zinn C, Gültig K, Fero ML, Frost D, Gummer AW, Roberts JM, Rubel EW, Hackney CM, Zenner HP (1999) Gene disruption of p27(Kip1) allows cell proliferation in the postnatal and adult organ of Corti. Proc Natl Acad Sci U S A 96:4084-4088.

Mak AC, Szeto IY, Fritzsch B, Cheah KS (2009) Differential and overlapping expression pattern of SOX2 and SOX9 in inner ear development. Gene Expr Patterns 9:444-453.

Minami S, Ohtani-Fujita N, Igata E, Tamaki T, Sakai T (1997) Molecular cloning and characterization of the human p27Kip1 gene promoter. FEBS Lett 411:1-6.

Miyagi S, Masui S, Niwa H, Saito T, Shimazaki T, Okano H, Nishimoto M, Muramatsu M, Iwama A, Okuda A (2008) Consequence of the loss of Sox2 in the developing brain of the mouse. FEBS Lett 582:2811-2815.

Morsli H, Choo D, Ryan A, Johnson R, Wu DK (1998) Development of the mouse inner ear and origin of its sensory organs. J Neurosci 18:3327-3335.

Nakamura T, Colbert MC, Robbins J (2006) Neural crest cells retain multipotential characteristics in the developing valves and label the cardiac conduction system. Circ Res 98:1547-1554.

Oesterle EC, Campbell S, Taylor RR, Forge A, Hume CR (2008) Sox2 and JAGGED1 expression in normal and drug-damaged adult mouse inner ear. J Assoc Res Otolaryngol 9:65-89.

Oesterle EC, Chien WM, Campbell S, Nellimarla P, Fero ML (2011) p27 (Kip1) is required to maintain proliferative quiescence in the adult cochlea and pituitary. Cell Cycle 10:1237-1248.

Ono K, Nakagawa T, Kojima K, Matsumoto M, Kawauchi T, Hoshino M, Ito J (2009) Silencing p27 reverses post-mitotic state of supporting cells in neonatal mouse cochleae. Mol Cell Neurosci 42:391-398.

Sage C, Huang M, Vollrath MA, Brown MC, Hinds PW, Corey DP, Vetter DE, Chen ZY (2006) Essential role of retinoblastoma protein in mammalian hair cell development and hearing. Proc Natl Acad Sci U S A 103:7345-7350.

Srinivasan RS, Dillard ME, Lagutin OV, Lin FJ, Tsai S, Tsai MJ, Samokhvalov IM, Oliver G (2007) Lineage tracing demonstrates the venous origin of the mammalian lymphatic vasculature. Genes Dev 21:2422-2432.

Stone JS, Cotanche DA (2007) Hair cell regeneration in the avian auditory epithelium. Int J Dev Biol 51:633-647.

Taranova OV, Magness ST, Fagan BM, Wu Y, Surzenko N, Hutton SR, Pevny LH (2006) SOX2 is a dose-dependent regulator of retinal neural progenitor competence. Genes Dev 20:1187-1202.

Wang C, Hou X, Mohapatra S, Ma Y, Cress WD, Pledger WJ, Chen J (2005) Activation of p27Kip1 Expression by E2F1. A negative feedback mechanism. J Biol Chem 280:12339-12343.

Weber T, Corbett MK, Chow LM, Valentine MB, Baker SJ, Zuo J (2008) Rapid cell-cycle reentry and cell death after acute inactivation of the retinoblastoma gene product in postnatal cochlear hair cells. Proc Natl Acad Sci U S A 105:781-785.

White PM, Doetzlhofer A, Lee YS, Groves AK, Segil N (2006) Mammalian cochlear supporting cells can divide and trans-differentiate into hair cells. Nature 441:984-987.

Young KM, Mitsumori T, Pringle N, Grist M, Kessaris N, Richardson WD (2010) An Fgfr3-iCreER(T2) transgenic mouse line for studies of neural stem cells and astrocytes. Glia 58:943-953.

Yu Y, Weber T, Yamashita T, Liu Z, Valentine MB, Cox BC, Zuo J (2010) In vivo proliferation of postmitotic cochlear supporting cells by acute ablation of the retinoblastoma protein in neonatal mice. J Neurosci 30:59275936. 